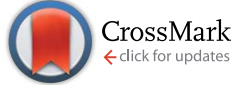

Cite this: RSC Adv., 2016, 6, 38579

Received 19th February 2016

Accepted 8th April 2016

DOI: $10.1039 / c 6 r a 04521 a$

www.rsc.org/advances

\title{
Oxysterols from an octocoral of the genus Gorgonia from the eastern Pacific of Panama†
}

\author{
Faviola Cardoso-Martínez, José M. de la Rosa, ${ }^{a}$ Ana R. Díaz-Marrero,,$_{\dagger}^{a}$ José Darias, ${ }^{a}$ \\ Luis D'Croz, ${ }^{\text {bc }}$ M. Dolores Jiménez-Antón, ${ }^{\text {de }}$ M. Jesús Corral, ${ }^{\text {de }}$ Rocío García, de \\ José M. Alunda ${ }^{\text {de }}$ and Mercedes Cueto*a
}

Eighteen new oxysterols have been isolated from a previously undescribed octocoral collected from the eastern Pacific of Panama. Their structures were determined based on spectroscopic evidence. The absolute configuration was established by derivatization with $(R)$ - and $(S)$-MPA. Antimicrobial and antileishmanial effects were evaluated.

\section{Introduction}

Sterols play an ecological role in marine organisms as substances in chemical defense against predators and competitor reef organisms. They also exhibit diverse biological activities, e.g., cytotoxicity, carcinogenesis, atherogenicity, hypocholesterolemia, mutagenesis and liver $\mathrm{X}$ receptor agonist (LXR). ${ }^{1}$ Certain oxysterols can regulate proteins involved in cholesterol efflux through activation of LXR, which is one means by which oxysterols affect cholesterol homeostasis. ${ }^{2,3}$ Steroids are a major group of secondary metabolites of soft corals and, among them, the subclass Octocorallia, particularly the sub-orders Holaxonia and Alcyoniina, produces the largest number of polyhydroxy sterols..$^{4-6}$ Most corals subject to chemical studies have been collected in the Indo Pacific, Caribbean and Red Sea, and very few on the Pacific side of Mesoamerica. ${ }^{7-9}$ This paper presents eighteen new oxysterols from an octocoral of the genus Gorgonia collected from the eastern Pacific coast of Panama. These compounds bear the same cholestane nucleus but display different oxidation patterns on the ring system.

All eighteen oxysterols show oxidations at C-3, C-5, C-6 and $\mathrm{C}-22$. Some of them exhibit additional oxidations on the steroidal nucleus and at C-25 on the side chain. Based on the

anstituto de Productos Naturales y Agrobiología del CSIC, Avda. Astrofísico F. Sánchez, 3, 38206 La Laguna, Tenerife, Spain. E-mail: mcueto@ipna.csic.es ${ }^{b}$ Departamento de Biología Marina y Limnología, Universidad de Panamá, Panama 'Smithsonian Tropical Research Institute, STRI, Box 0843-03092, Balboa, Panama

${ }^{d}$ Departamento de Sanidad Animal (Grupo UCM 910993 ICPVet), Facultad de Veterinaria, Universidad Complutense de Madrid, 28040, Madrid, Spain

'Instituto de Investigación Hospital 12 de Octubre, Avda de Córdoba, s/n, 28041, Madrid, Spain

$\dagger$ Electronic supplementary information (ESI) available: ${ }^{1} \mathrm{H}$ and ${ }^{13} \mathrm{C}$ NMR spectra of compounds 1-18. See DOI: 10.1039/c6ra04521a

\$ Present address: Department of Organic Chemistry, University Institute of Bio-Organic Chemistry "Antonio González" (IUBO-CIBICAN), Universidad de La Laguna, 38206 Tenerife, Spain. different positions of oxidation, this set of steroids can be divided into two groups as depicted in Fig. 1 (groups A and B). All steroids of group A have also been oxidized at C-19 and are distributed into two series: $3 \alpha$-oxysteroids (1-11), and $3 \beta$-oxysteroids (12-14), three of them bear a C-19-C-6 oxygen bridge (9-11). The remaining 15-18 compose group B. Compound 15 contains an extra oxidation position at C-9. Compound $\mathbf{1 6}$ possesses four oxidized carbons in the steroidal nucleus (C-3, C-5, C-6 and C-9) and conserves the C-19 methyl group. Compound 17 does not have any extra oxidation positions at the steroidal nucleus. Finally, compound $\mathbf{1 8}$ is the sole oxysterol of the $3 \alpha$-series that conserves the $\mathrm{C}-19$ methyl group and presents additional oxidations at C-9 and C-11.

\section{Results and discussion}

From the crude extract of Gorgonia sp. collected off Aleta Island (Panama), compounds 1-18 were obtained after reversed-phase flash chromatography followed by gel filtration and successive HPLC.

Compound 1 was isolated as an amorphous solid $[\alpha]_{\mathrm{D}}^{20}-49$ (c $0.35, \mathrm{CH}_{2} \mathrm{Cl}_{2}$ ). Its HREIMS showed a peak at 494.3622 which corresponds to the empirical formula $\mathrm{C}_{29} \mathrm{H}_{50} \mathrm{O}_{6}[\mathrm{M}]^{+}$, indicating five degrees of unsaturation. Absorptions for hydroxyl and carbonyl groups at 3420 and $1716 \mathrm{~cm}^{-1}$ were observed in the IR spectrum. The ${ }^{13} \mathrm{C}$ NMR and DEPT spectra of $\mathbf{1}$ (Table 1 ) showed the presence of 29 carbon signals assigned to $5 \times \mathrm{CH}_{3}$ (one from an acetyl group), $11 \times \mathrm{CH}_{2}$ (including one attached to hydroxyl group), $9 \times \mathrm{CH}$ (three bearing oxygen) and 4 quaternary carbons (one carbonyl, and one $\mathrm{sp}^{3}$ attached to oxygen). The analysis of ${ }^{1} \mathrm{H}$ and ${ }^{13} \mathrm{C}$ NMR data indicates that 1 must be a cholestane steroid with five oxidation sites. 2D NMR experiments confirmed its structure and allowed to place the three hydroxyl groups and the acetoxy group in the molecule. HMBC correlations of $\mathrm{H}_{2}-19$ with $\mathrm{C}-1, \mathrm{C}-5, \mathrm{C}-9$ and $\mathrm{C}-10$ indicate that the characteristic Me-19 of the cholestane skeleton is oxidized to 

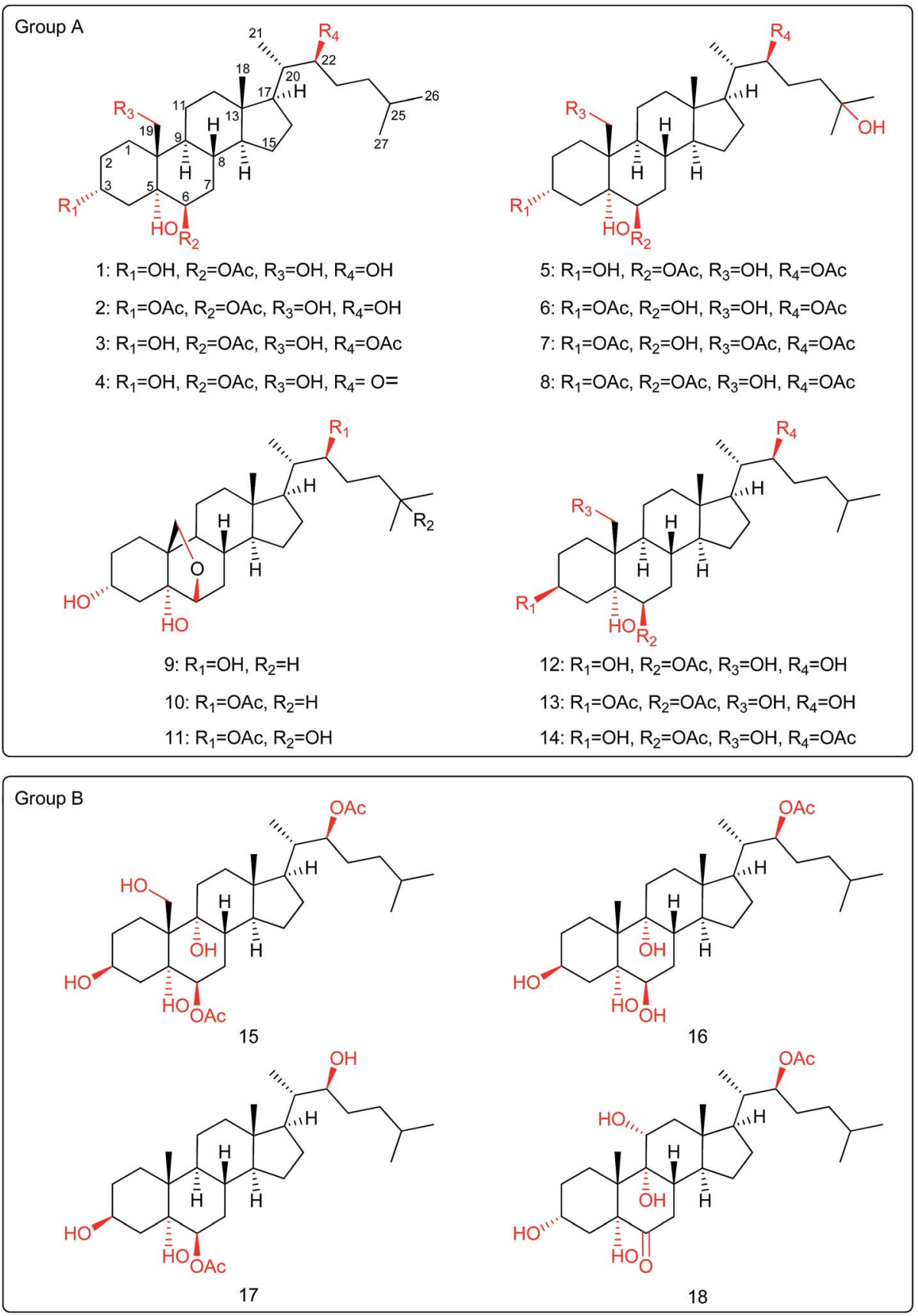

Fig. 1 New steroids isolated from Gorgonia sp.

a hydroxymethyl group. Also HMBC correlations of $\mathrm{H}-3$ with C-5 established the presence of hydroxyl groups at C-3 and C-5 and the $\mathrm{HMBC}$ correlation of $\mathrm{H}-22$ with $\mathrm{C}-21$ and $\mathrm{C}-24$ indicated that the third hydroxyl group is placed at C-22. Finally the HMBC correlation of H-6 with the carbonyl at $\delta_{\mathrm{C}} 169.6 \mathrm{ppm}$ established the presence of an acetoxy group at C-6. Relative and absolute configuration will be discussed in later.

From accurate mass measurement, compound 2 was found to possess a molecular formula of $\mathrm{C}_{31} \mathrm{H}_{52} \mathrm{O}_{7}\left(\mathrm{~m} / \mathrm{z} 536.3731[\mathrm{M}]^{+}\right)$ with six degrees of unsaturation. The spectroscopic data of 2 were very similar to those of $\mathbf{1}$, the most significant differences being the presence of signals indicative of a second acetoxy group $\left(\delta_{\mathrm{C}} 21.4\right.$ and $\left.\delta_{\mathrm{C}} 169.0\right)$ and the chemical shift of C-3 $\left(\delta_{\mathrm{H}}\right.$ 5.30 , br s; $\left.\delta_{\mathrm{C}} 71.2\right)$. These differences can be explained by the presence of an acetoxy instead of the hydroxyl group at C-3 found in compound $\mathbf{1}$.

Compound 3 was found to have the same molecular formula as $2\left(\mathrm{C}_{31} \mathrm{H}_{52} \mathrm{O}_{7}\left(\mathrm{~m} / \mathrm{z} 536.3688[\mathrm{M}]^{+}\right)\right.$. The spectroscopic data of 3 were very similar to those of $\mathbf{1}$, the most significant differences being the presence of signals indicative of a second acetoxy group $\left(\delta_{\mathrm{H}} 2.02, \mathrm{~s} ; \delta_{\mathrm{C}} 21.2\right.$ and $\left.\delta_{\mathrm{C}} 170.9\right)$ and the chemical shift of C-22 $\left(\delta_{\mathrm{H}} 4.90, \mathrm{dd}, J=7.6,7.6 \mathrm{~Hz} ; \delta_{\mathrm{C}} 76.5\right)$. These differences can 
Table $1{ }^{13} \mathrm{C}$ NMR (125 MHz) data for compounds 1-18 in $\mathrm{CDCl}_{3}$

\begin{tabular}{|c|c|c|c|c|c|c|c|c|c|c|c|c|c|c|c|c|c|c|}
\hline Pos. & 1 & 2 & 3 & 4 & 5 & 6 & 7 & 8 & 9 & 10 & 11 & 12 & 13 & 14 & 15 & 16 & 17 & 18 \\
\hline 1 & 21.8 & 22.3 & 21.8 & 21.8 & 21.7 & 26.3 & 21.8 & 22.2 & 18.7 & 18.7 & 18.7 & 25.4 & 25.5 & 25.5 & 25.8 & 26.9 & 32.0 & 27.3 \\
\hline 2 & 29.5 & 26.1 & 29.5 & 29.5 & 29.2 & 25.9 & 25.9 & 26.1 & 28.8 & 28.8 & 28.7 & 31.1 & 27.2 & 31.2 & 30.9 & $30.3^{a}$ & 30.7 & 31.9 \\
\hline 3 & 68.4 & 71.2 & 68.4 & 68.4 & 68.2 & 71.5 & 71.4 & 71.1 & 67.4 & 67.4 & 67.4 & 67.2 & 70.6 & 67.2 & 66.9 & 67.4 & 67.3 & 65.9 \\
\hline 4 & 36.1 & 34.8 & 36.2 & 36.1 & 36.0 & 35.1 & 34.9 & 34.7 & 37.3 & 37.3 & 37.3 & 40.9 & 37.3 & 41.1 & 40.7 & 40.7 & 40.6 & 31.9 \\
\hline 5 & 73.6 & 73.0 & 73.6 & 73.6 & 73.7 & 74.4 & 73.9 & 73.0 & 75.9 & 75.9 & 75.9 & 74.6 & 74.1 & 74.6 & 75.8 & 77.6 & 75.3 & 81.8 \\
\hline 6 & 76.2 & 75.8 & 76.1 & 76.0 & 76.0 & 74.6 & 74.4 & 75.7 & 80.8 & 80.8 & 80.8 & 76.1 & 76.4 & 76.1 & 76.4 & 76.0 & 76.1 & 212.4 \\
\hline 7 & 30.3 & 30.4 & 30.3 & 30.3 & 30.2 & 33.6 & 34.3 & 30.4 & 30.6 & 30.6 & 30.6 & 30.9 & 30.9 & 31.0 & 29.5 & 29.1 & 31.4 & 36.6 \\
\hline 8 & 31.2 & 31.2 & 31.2 & 31.2 & 31.1 & 31.3 & 30.6 & 31.1 & 33.4 & 33.4 & 33.4 & 31.2 & 31.3 & 31.2 & 33.7 & 32.4 & 30.8 & 40.1 \\
\hline 9 & 45.5 & 45.3 & 45.4 & 45.5 & 45.4 & 45.6 & 45.2 & 45.3 & 44.7 & 44.7 & 44.7 & 45.5 & 45.3 & 45.5 & 78.5 & 78.8 & 45.4 & 78.3 \\
\hline 10 & 44.8 & 44.6 & 44.8 & 44.8 & 44.7 & 43.2 & 43.0 & 44.5 & 44.9 & 44.8 & 44.8 & 43.6 & 43.7 & 43.6 & 46.7 & 41.2 & 38.5 & 49.0 \\
\hline 11 & 22.5 & 22.5 & 22.5 & 22.3 & 22.4 & 21.1 & 22.1 & 22.4 & 22.1 & 22.1 & 22.1 & 22.6 & 22.7 & 22.8 & 20.3 & $29.7^{a}$ & 21.2 & 69.7 \\
\hline 12 & 40.5 & 40.5 & 40.5 & 40.4 & 40.4 & 40.5 & 40.4 & 40.5 & 40.1 & 40.2 & 40.2 & 40.5 & 40.5 & 40.4 & 34.7 & 34.8 & 40.0 & 46.3 \\
\hline 13 & 42.8 & 42.8 & 42.8 & 43.1 & 42.7 & 43.0 & 42.7 & 42.6 & 43.2 & 43.1 & 43.2 & 42.8 & 42.8 & 42.8 & 42.6 & 42.6 & 42.7 & 42.4 \\
\hline 14 & 56.0 & 56.1 & 56.1 & 55.5 & 56.0 & 56.8 & 56.1 & 56.1 & 54.8 & 54.8 & 54.8 & 56.1 & 56.2 & 56.1 & 48.6 & 48.7 & 55.8 & 47.7 \\
\hline 15 & 24.0 & 24.0 & 24.0 & 24.3 & 24.0 & 24.0 & 24.1 & 24.0 & 23.5 & 23.5 & 23.5 & 24.0 & 24.0 & 24.0 & 24.0 & 24.0 & 24.1 & 23.6 \\
\hline 16 & 27.7 & 27.7 & 28.0 & 27.7 & 28.0 & 28.1 & 28.1 & 28.0 & 27.9 & 28.2 & 28.2 & 27.7 & 27.7 & 28.1 & 27.9 & 28.0 & 27.7 & 27.8 \\
\hline 17 & 52.6 & 52.6 & 52.6 & 52.1 & 52.5 & 52.6 & 52.6 & 52.6 & 52.7 & 52.6 & 52.6 & 52.5 & 52.5 & 52.6 & 52.5 & 52.6 & 52.7 & 52.2 \\
\hline 18 & 12.4 & 12.4 & 12.2 & 12.7 & 12.2 & 12.3 & 12.0 & 12.2 & 12.4 & 12.2 & 12.2 & 12.4 & 12.4 & 12.3 & 11.2 & 11.0 & 12.1 & 12.0 \\
\hline 19 & 62.7 & 62.5 & 62.7 & 62.7 & 62.5 & 65.6 & 64.0 & 62.4 & 69.2 & 69.2 & 69.2 & 62.5 & 62.6 & 62.6 & 62.7 & 20.0 & 16.5 & 22.4 \\
\hline 20 & 40.2 & 40.2 & 38.9 & 49.6 & 39.0 & 39.2 & 39.2 & 39.1 & 40.2 & 38.8 & 39.1 & 40.2 & 40.2 & 38.9 & 38.9 & 38.9 & 40.3 & 38.8 \\
\hline 21 & 11.5 & 11.5 & 12.7 & 16.5 & 12.7 & 12.7 & 12.7 & 12.7 & 11.5 & 12.7 & 12.7 & 11.4 & 11.4 & 12.7 & 12.7 & 12.7 & 11.5 & 12.7 \\
\hline 22 & 73.9 & 73.9 & 76.5 & 214.8 & 76.6 & 76.6 & 76.6 & 76.5 & 73.9 & 76.6 & 76.6 & 73.9 & 73.9 & 76.5 & 76.4 & 76.4 & 73.9 & 76.1 \\
\hline 23 & 33.2 & 33.3 & 29.9 & 39.5 & 26.9 & 27.1 & 27.1 & 27.0 & 33.2 & 29.9 & 27.0 & 33.2 & 33.2 & 30.0 & 30.0 & 29.9 & 33.3 & 29.9 \\
\hline 24 & 35.7 & 35.7 & 34.9 & 32.5 & 39.7 & 39.8 & 39.8 & 39.7 & 35.7 & 34.9 & 39.8 & 35.7 & 35.7 & 34.9 & 35.0 & 35.0 & 35.7 & 34.9 \\
\hline 25 & 28.2 & 28.2 & 28.1 & 27.5 & 70.7 & 70.7 & 70.7 & 70.7 & 28.2 & 28.1 & 70.7 & 28.2 & 28.2 & 28.0 & 28.0 & 28.0 & 28.2 & 28.0 \\
\hline 26 & 22.7 & 22.7 & 22.7 & 22.4 & 29.3 & 29.4 & 29.5 & 29.4 & 22.7 & 22.7 & 29.4 & 22.5 & 22.6 & 22.7 & 22.6 & 22.6 & 22.7 & 22.6 \\
\hline 27 & 22.5 & 22.5 & 22.4 & 22.4 & 29.1 & 29.2 & 29.2 & 29.2 & 22.6 & 22.4 & 29.2 & 22.5 & 22.5 & 22.4 & 22.4 & 22.4 & 22.6 & 22.6 \\
\hline $3 \mathrm{CO}$ & - & 169.0 & - & - & - & 169.1 & 169.0 & 168.9 & - & - & - & - & 170.7 & - & - & - & - & - \\
\hline $3 \mathrm{COCH}_{3}$ & - & 21.4 & - & - & - & 21.5 & 21.5 & 21.4 & - & - & - & - & 21.3 & - & - & - & - & - \\
\hline $6 \mathrm{CO}$ & 169.6 & 169.5 & 169.5 & 169.6 & 169.7 & - & - & 169.5 & - & - & - & 169.9 & 169.6 & 169.8 & 169.4 & - & 170.1 & - \\
\hline $6 \mathrm{COCH}_{3}$ & 21.4 & 21.4 & 21.4 & 21.4 & 21.4 & - & - & 21.3 & - & - & - & 21.4 & 21.4 & 21.2 & 21.4 & - & 21.4 & - \\
\hline $19 C O$ & - & - & - & - & - & - & 171.0 & - & - & - & - & - & - & - & - & - & - & - \\
\hline $19 \mathrm{COCH}_{3}$ & - & - & - & - & - & - & $21.2^{a}$ & - & - & - & - & - & - & - & - & - & - & - \\
\hline $22 \mathrm{CO}$ & - & - & 170.9 & - & 171.1 & 171.0 & 170.9 & 171.0 & - & 170.9 & 170.9 & - & - & 171.0 & 170.8 & 171.2 & - & 170.8 \\
\hline $22 \mathrm{COCH}_{3}$ & - & - & 21.2 & - & 21.2 & 21.2 & $21.1^{a}$ & 21.1 & - & 21.2 & 21.1 & - & - & 21.2 & 21.2 & 21.2 & - & 21.2 \\
\hline
\end{tabular}

be explained by the presence of an acetoxy instead of the hydroxyl group at C-22 found in compound $\mathbf{1}$.

The molecular formula of 4 was determined as $\mathrm{C}_{29} \mathrm{H}_{48} \mathrm{O}_{6}(\mathrm{~m} / \mathrm{z}$ 492.3434 $[\mathrm{M}]^{+}$). The spectroscopic data of 4 indicate that it possesses the same steroidal nucleus as 1 . Therefore differences must be on the side chain that must contain a ketone $\left(\delta_{\mathrm{C}} 214.8\right)$. HMBC correlation between the carbonyl group and $\mathrm{H}-20, \mathrm{H}_{3}-21$ and $\mathrm{H}_{2}-23$ confirmed the presence of a ketone at C-22 instead of the hydroxyl group of $\mathbf{1}$.

Compound 5 possesses a molecular formula of $\mathrm{C}_{31} \mathrm{H}_{52} \mathrm{O}_{8}(\mathrm{~m} /$ $z 552.3671[\mathrm{M}]^{+}$) with six degrees of unsaturation. Comparison of NMR data of $\mathbf{3}$ and 5 suggests that both compounds bear the same substituents and the same configuration on the steroidal nucleus. Differences appear on the side chain: a singlet at $\delta_{\mathrm{H}}$ $1.19 \mathrm{~s}(6 \mathrm{H})$ instead of the doublets of 3 and a quaternary carbon at $\delta_{\mathrm{C}} 70.7(\mathrm{C}-25)$ instead of the methine of 3 . These data indicate that 5 contains a hydroxyl group at C-25.

Molecular formula of $\mathbf{6}$ is the same as that of $5\left(\mathrm{C}_{31} \mathrm{H}_{52} \mathrm{O}_{8} \mathrm{~m} / \mathrm{z}\right.$ $\left.552.3589[\mathrm{M}]^{+}\right)$. Comparison of their NMR data indicates that they must be positional isomers. HMBC correlation of the carbonyl at $\delta_{\mathrm{C}} 169.1$ with $\mathrm{H}-3\left(\delta_{\mathrm{H}} 5.32\right)$ and ${ }^{1} \mathrm{H}$ and ${ }^{13} \mathrm{C} \mathrm{NMR}$ chemical shifts of C-6 $\left(\delta_{\mathrm{H}} 3.60\right.$, dd, $\left.J=2.8,2.8 \mathrm{~Hz} ; \delta_{\mathrm{C}} 74.6\right)$ indicate that 6 contains a hydroxyl at C- 6 and an acetoxy group at $\mathrm{C}-3$.

The presence of three acetoxy groups in 7 is deduced from its molecular formula, $\mathrm{C}_{33} \mathrm{H}_{54} \mathrm{O}_{9}\left(\mathrm{~m} / \mathrm{z} 594.3768[\mathrm{M}]^{+}\right)$and its ${ }^{13} \mathrm{C}$ NMR data (Table 1). From the comparison of the NMR data of 7 and 6 it can be deduced that 7 is the C-19 acetoxy derivative of 6 since the most significant differences are found at C-19 $\left(\delta_{\mathrm{H}} 4.65\right.$, $\left.\mathrm{d}, J=12.9 \mathrm{~Hz}, 4.27, \mathrm{~d}, J=12.9 \mathrm{~Hz} ; \delta_{\mathrm{C}} 64.0\right)$ and it was confirmed by the HMBC correlation of the carbonyl at $\delta_{\mathrm{C}} 171.0$ with $\mathrm{H}_{2}-19$.

The molecular formula $\left.\mathrm{C}_{33} \mathrm{H}_{54} \mathrm{O}_{9}(\mathrm{~m} / z \text { 594.3769 [M] }]^{+}\right)$and NMR data of $\mathbf{8}$ indicates that $\mathbf{8}$ and 7 are positional isomers. Chemical shifts of $\mathrm{H}-3\left(\delta_{\mathrm{H}} 5.28\right.$, br s) and $\mathrm{H}-22\left(\delta_{\mathrm{H}} 4.93\right.$, dd, $J=$ $6.3,6.4)$ indicated that positions $\mathrm{C}-3$ and $\mathrm{C}-22$ are acetylated in 8 as it occurs in 7. Chemical shifts of $\mathrm{H}-6\left(\delta_{\mathrm{H}} 4.68\right.$, br s $)$ and $\mathrm{H}_{2}-19$ $\left(\delta_{\mathrm{H}} 4.18, \mathrm{~d}, J=12.4 \mathrm{~Hz}, 3.75, \mathrm{~d}, J=12.4 \mathrm{~Hz}\right)$ together with the HMBC correlation of the carbonyl at $\delta_{\mathrm{C}} 169.5$ with H-6 established that the third acetoxy group is located at C-6.

Compound 9 was isolated as an amorphous solid. Its HREIMS showed a peak at $m / z 434.3389$ which corresponds to the empirical formula $\mathrm{C}_{27} \mathrm{H}_{46} \mathrm{O}_{4}$, indicating five degrees of 
unsaturation. In the IR spectrum absorptions for hydroxyl at $3416 \mathrm{~cm}^{-1}$ were observed but no absorption for carbonyl groups. From the ${ }^{1} \mathrm{H}$ and ${ }^{13} \mathrm{C}$ NMR (Tables 1 and 3) data it can be deduced that 9 is a steroid with positions C-3, C-5, C-6, C-19 and C-22 oxidized but its molecular formula only shows four oxygen atoms. Comparison of its NMR data with those of $\mathbf{1}$, shows that the side chain is the same for both compounds and differences are found at C-6 and C-19. In 9 chemical shifts of C-6 and $\mathrm{C}-19$ move downfield, and $\mathrm{H}_{2}-19$ coupling constants change from $12.6 \mathrm{~Hz}$ to $8.5 \mathrm{~Hz}$, which indicate that a cyclic ether must connect C-6 and C-19 thus satisfying the five degrees of unsaturation of the molecular formula.

From accurate mass measurement, compound $\mathbf{1 0}$ was found to have a molecular formula of $\mathrm{C}_{29} \mathrm{H}_{48} \mathrm{O}_{5}(\mathrm{~m} / \mathrm{z} 499.3386[\mathrm{M}+$ $\mathrm{Na}]^{+}$) with six degrees of unsaturation. Absorptions for hydroxyl and carbonyl groups at 3416 and $1731 \mathrm{~cm}^{-1}$ were observed in the IR spectrum. The spectroscopic data of $\mathbf{1 0}$ were very similar to those of $\mathbf{9}$, the most significant differences being the presence of signals indicative of an acetoxy group $\left(\delta_{\mathrm{C}} 21.1\right.$ and $\delta_{\mathrm{C}}$ $170.9)$ and the chemical shift of C-22 $\left(\delta_{\mathrm{H}} 4.91, \mathrm{dd}, J=6.6,6.9 \mathrm{~Hz}\right.$; $\delta_{\mathrm{C}}$ 76.6). These differences can be explained by the presence of an acetoxy group at C-22 instead of the hydroxyl group found in compound 9.

Compound 11 possesses a molecular formula of $\mathrm{C}_{29} \mathrm{H}_{48} \mathrm{O}_{6}$ $\left(\mathrm{m} / z 492.3455[\mathbf{M}]^{+}\right)$with six degrees of unsaturation. Comparison of NMR data of $\mathbf{1 0}$ and $\mathbf{1 1}$ suggests that both compounds possess the same substituents and the same configuration on the steroidal nucleus. Differences appear on the side chain. Me26 and Me-27 show as a singlet $\left(\delta_{\mathrm{H}} 1.20 \mathrm{~s}[6 \mathrm{H}]\right)$ instead of the doublets of 10 and C-25 appears as a quaternary carbon at $\delta_{\mathrm{C}}$ 70.7 instead of the methine of $\mathbf{1 0}$. These data indicate that $\mathbf{1 1}$ contains another hydroxyl group at C-25.

There is a precedent of an oxysterol containing a C-19-C-6 oxygen bridge that has been obtained as the result of the spontaneous cyclization of its C-6/C-19 di-hydroxyl derivative. ${ }^{\mathbf{1 0}}$ However, when a sample of 6 was stirred in $\mathrm{CDCl}_{3}$ at room temperature for 30 days no changes were observed in the starting material and no ether derivative was detected.

Compound $\mathbf{1 2}$ possesses the same molecular formula as $\mathbf{1}$ $\mathrm{C}_{29} \mathrm{H}_{50} \mathrm{O}_{6}\left(m / z 494.3627[\mathrm{M}]^{+}\right)$and their ${ }^{1} \mathrm{H}$ and ${ }^{13} \mathrm{C}$ NMR data are very similar. The most significant difference is the shape of $\mathrm{H}-3$ (br s) in 1 whereas in 12 it appears as a well resolved doublet of doublets (dddd, $J=4.6,4.6,10.4,10.4$ ) which indicates that both compounds are epimers at C-3.

The same relationship is deduced for the epimers at C-3 13 and $\mathbf{2}$ and for the couple $\mathbf{3}$ and $\mathbf{1 4}$.

Compound 15 was isolated as an amorphous solid whose molecular formula was established as $\mathrm{C}_{31} \mathrm{H}_{52} \mathrm{O}_{8}$ by HREIMS $\mathrm{m} / \mathrm{z}$ $552.3663[\mathrm{M}]^{+}$, IR absorptions at 3394, 1732 and $1718 \mathrm{~cm}^{-1}$ indicated the presence of hydroxyl and acetoxy groups. The ${ }^{13} \mathrm{C}$ NMR and DEPT spectra of $\mathbf{1 5}$ (Table 1) showed the presence of 31 carbon signals assigned to $6 \times \mathrm{CH}_{3}$ (two from acetoxy groups), $11 \times \mathrm{CH}_{2}$ (one bonded to hydroxyl group), $8 \times \mathrm{CH}$ (three attached to oxygen) and 6 quaternary carbons (two from acetoxy groups, and two $\mathrm{sp}^{3}$ bearing oxygen). 1D and 2D NMR indicate that acetoxy groups are located at C-6 and C-22 and positions C-3, C-5 and C-19 are linked to hydroxyl groups.
HMBC correlation of the additional oxidized carbon at $\delta_{\mathrm{C}} 78.5$ ppm with $\mathrm{H}_{2}-19$ indicates that another tertiary hydroxyl group must be at C-9. This is the first example of a steroid with this oxidation pattern on the steroidal nucleus.

HRESIMS $[\mathrm{M}]^{+} \mathrm{m} / \mathrm{z} 494.3580$ established the molecular formula $\mathrm{C}_{29} \mathrm{H}_{50} \mathrm{O}_{6}$ for 16 . IR absorptions at 3375 , and $1731 \mathrm{~cm}^{-1}$ indicated the presence of hydroxyl and acetoxy groups. The ${ }^{13} \mathrm{C}$ NMR and DEPT spectra of 16 (Table 1) showed the presence of 29 carbon signals assigned to $6 \times \mathrm{CH}_{3}$ (one from an acetoxy group), $10 \times \mathrm{CH}_{2}, 8 \times \mathrm{CH}$ (three attached to oxygen) and 5 quaternary carbons (one from acetoxy group, and two $\mathrm{sp}^{3}$ attached to oxygen). NMR data indicated the presence of the two methyl groups of the steroidal nucleus, $\mathrm{H}_{3}-18$ and $\mathrm{H}_{3}-19$. HMBC correlation of the carbonyl at $\delta_{\mathrm{C}} 171.2$ with $\mathrm{H}-22\left(\delta_{\mathrm{H}} 4.91\right.$, dd, $J=$ $6.3,7.2 \mathrm{~Hz}$ ) placed the acetoxy group at $\mathrm{C}-22$. Therefore positions C-3, C-5, C-6 and C-9 are attached to hydroxyl groups. Thus the structure of $\mathbf{1 6}$ was established as represented in Fig. 1.

Molecular formula of 17 was established as $\mathrm{C}_{29} \mathrm{H}_{50} \mathrm{O}_{5}(\mathrm{~m} / \mathrm{z}$ 478.3641 $[\mathrm{M}]^{+}$). The ${ }^{13} \mathrm{C}$ NMR and DEPT spectra of 17 (Table 1) showed the presence of 29 carbon signals assigned to $6 \times \mathrm{CH}_{3}$ (one from an acetoxy group), $10 \times \mathrm{CH}_{2}, 9 \times \mathrm{CH}$ (three bonded to oxygen) and 4 quaternary carbons (one from acetoxy group, and one $\mathrm{sp}^{3}$ attached to oxygen). The spectroscopic data of $\mathbf{1 7}$ were very similar to those of $\mathbf{1 2}$, indicating that they possess the same side chain and substituents of the steroidal nucleus at $\mathrm{C}$ 3, C-5 and C- 6 remain the same. The most significant difference being the presence of a methyl group at $\delta_{\mathrm{C}} 16.5 ; \delta_{\mathrm{H}} 1.14(\mathrm{~s})$ instead of the hydroxymethyl group found in $12\left(\delta_{\mathrm{C}} 62.5 ; \delta_{\mathrm{H}}\right.$ $4.20, \mathrm{~d}, J=12.3 \mathrm{~Hz}, 3.89, \mathrm{~d}, J=12.3 \mathrm{~Hz}$ ). The presence of the methyl group at $\mathrm{C}-10$ was confirmed by the HMBC correlations of $\mathrm{H}_{3}-19$ with C-1, C-5 and C-9. Therefore the structure of 17 was established as represented on Fig. 1.

Compound 18 was isolated as an amorphous solid. Its HREIMS showed a peak at $m / z 508.3397[\mathrm{M}]^{+}$which corresponds to the empirical formula $\mathrm{C}_{29} \mathrm{H}_{48} \mathrm{O}_{7}$, indicating six degrees of unsaturation. Absorptions for hydroxyl and carbonyl groups at 3438 and $1732 \mathrm{~cm}^{-1}$ were observed in the IR spectrum. The ${ }^{13} \mathrm{C}$ NMR and DEPT spectra of $\mathbf{1 8}$ (Table 1) showed the presence of 29 carbon signals assigned to $6 \times \mathrm{CH}_{3}$ (one from an acetoxy group), $9 \times \mathrm{CH}_{2}, 8 \times \mathrm{CH}$ (three bonded to oxygen) and 6 quaternary carbons (one ketone, one from an acetoxy group, and two $\mathrm{sp}^{3}$ bearing oxygen). The comparison of its NMR data with those of the previously described steroids indicates that its side chain contains an acetoxy group at C-22. HMBC correlations of $\mathrm{H}_{3}-18$ with $\mathrm{C}-12, \mathrm{C}-13, \mathrm{C}-14$ and $\mathrm{C}-17$ together with the COSY correlation $\mathrm{H}-11 / \mathrm{H}_{2}-12$ placed a hydroxyl group at $\mathrm{C}-11$. HMBC correlations of $\mathrm{H}_{3}-19$ with $\mathrm{C}-1, \mathrm{C}-5, \mathrm{C}-9$ and $\mathrm{C}-10$ placed the tertiary hydroxyl groups at C-5 and C-9. Chemical shift of C-7 $\left(\delta_{\mathrm{C}} 36.6\right)$ and $\mathrm{H}_{2}-7\left(\delta_{\mathrm{H}} 2.81\right.$, dd, $J=13.5,13.5 ; 2.19$, d, $J=13.2)$ together with the HMBC correlations of the ketone $\left(\delta_{\mathrm{C}}\right.$ 212.4) with $\mathrm{H}_{2}-7$ indicated that the ketone must be at C-6.

\section{Relative configuration of the steroidal nucleus}

The relative configurations of the 18 new steroids were established based on 2D NOESY experiments, molecular mechanics calculations and coupling constants. The fusion of the rings of 


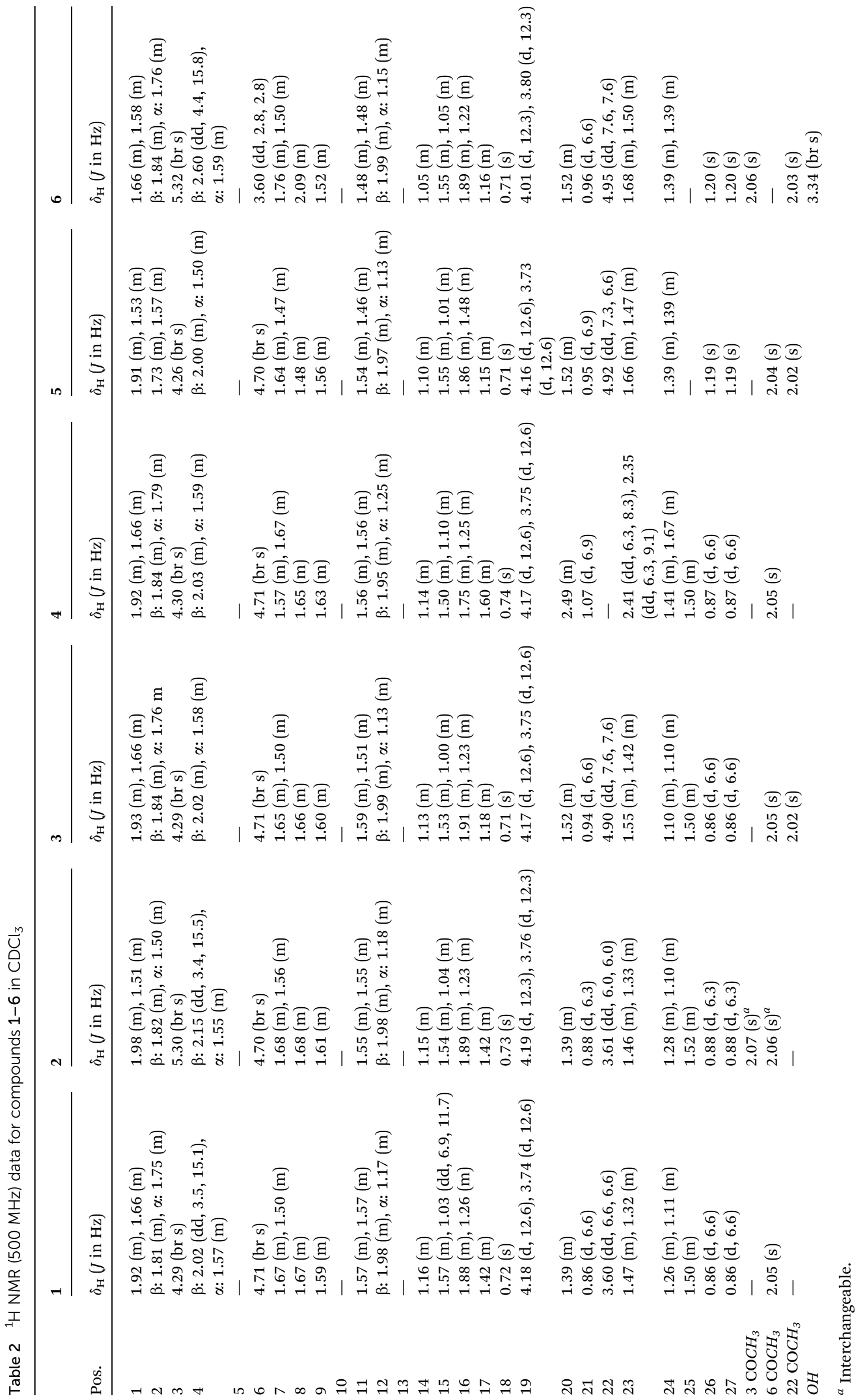




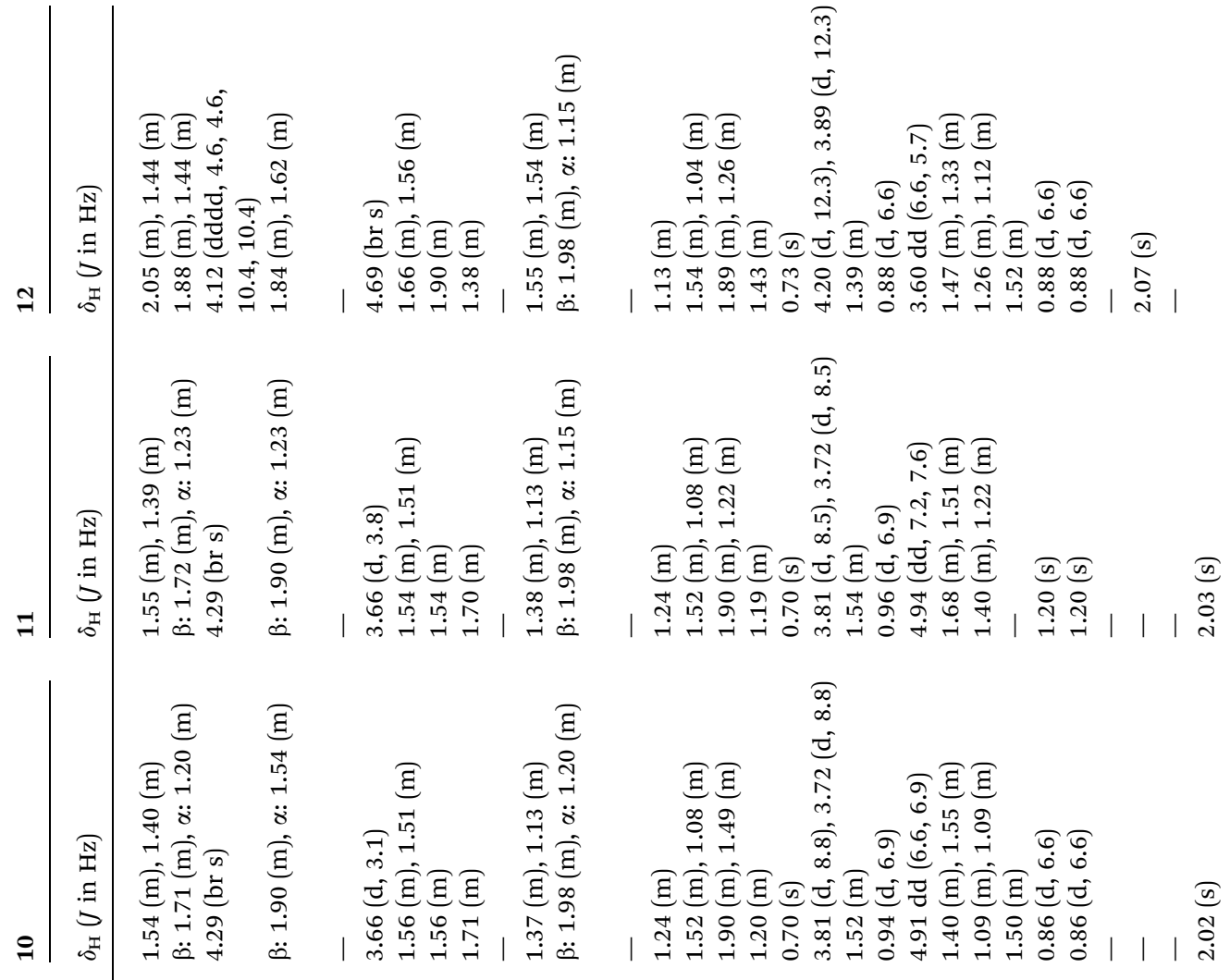

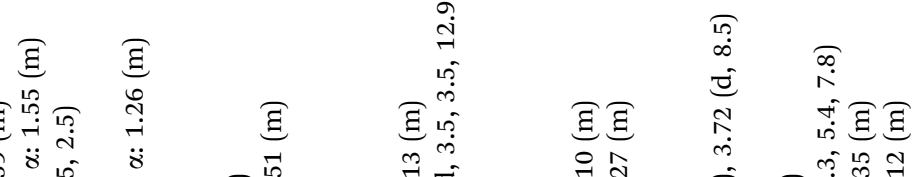

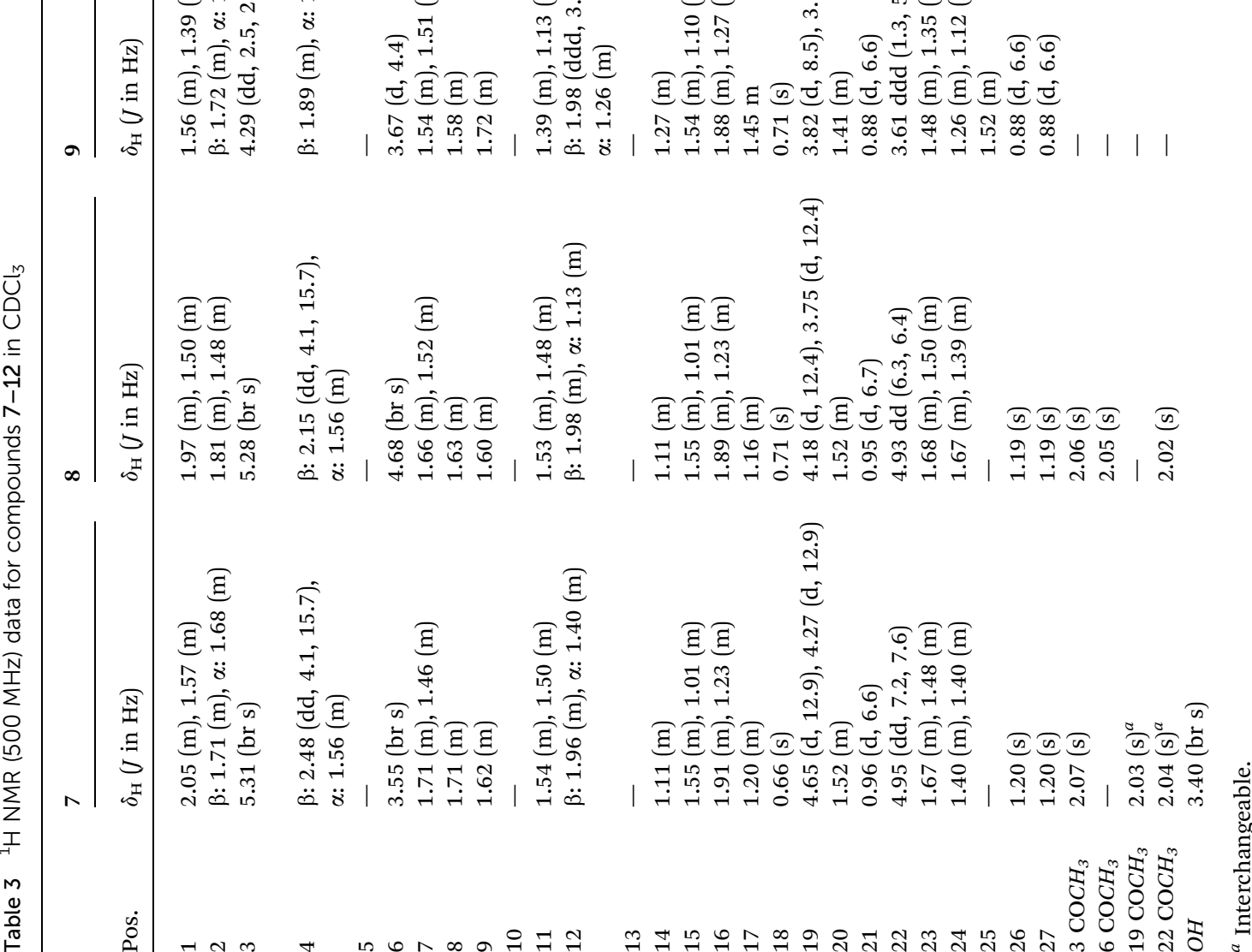




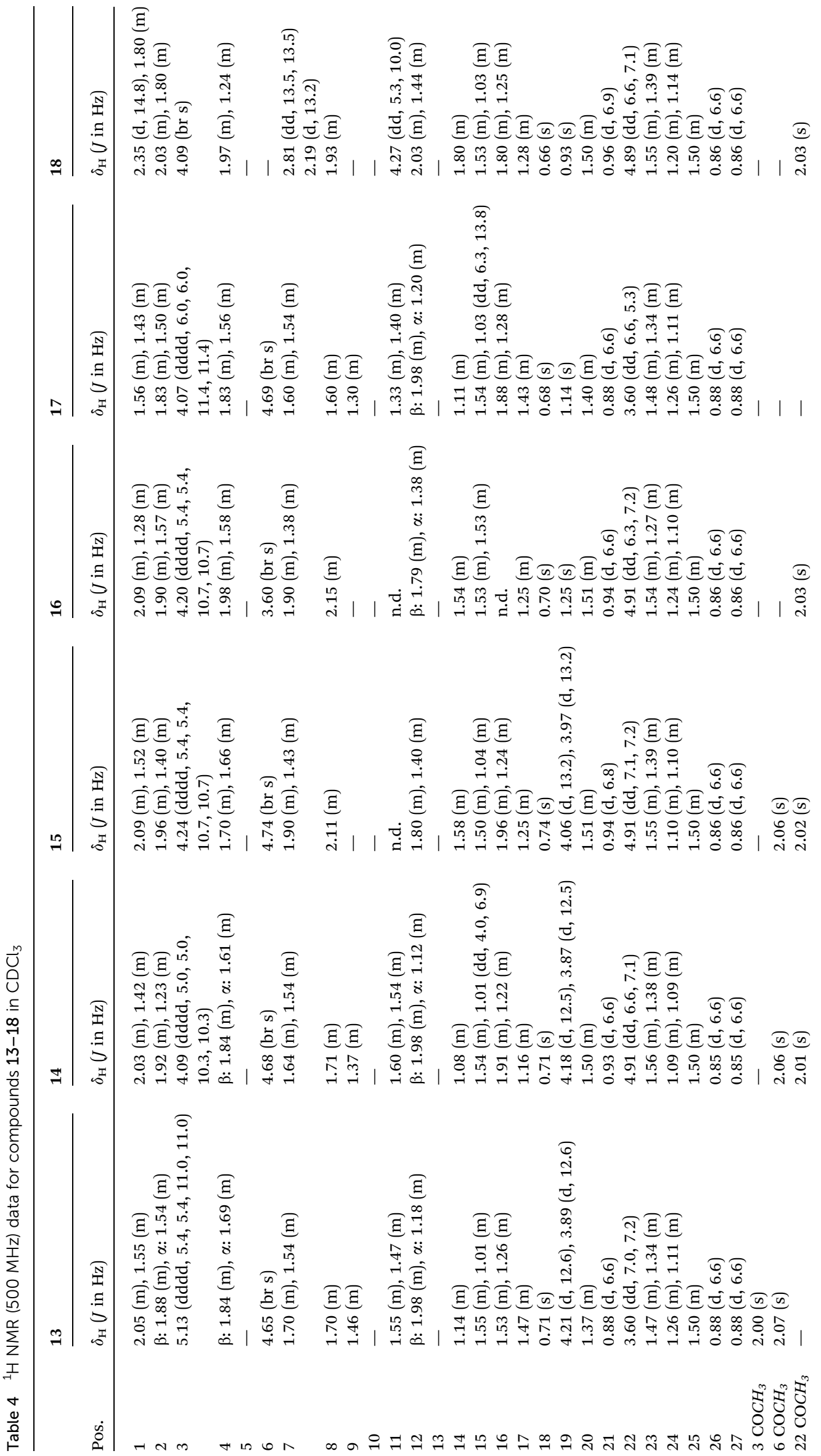


the steroidal nucleus was established as all trans due to the observed NOEs between $\mathrm{H}_{3}-18$ and $\mathrm{H}_{3}-19$ (or $\mathrm{H}_{2}-19$ ) with $\mathrm{H}-8$ for all the 18 compounds. Therefore the six member rings must adopt a chair conformation. Except for 18, in all compounds, the H-6 signal appears either as a br s or with small coupling constants $(\approx 2.8-4.4 \mathrm{~Hz})$, which indicates that $\mathrm{H}-6$ must be on equatorial disposition and, therefore the substituent at C-6 must be $\beta$.

On the other hand, attending to the $\mathrm{H}-3$ coupling constants, we can differentiate compounds in two series: $\beta$ and $\alpha$. The $\alpha$ series composes 1-11 and 18, with the substituent (hydroxyl or acetoxy group) at C-3 in $\alpha$ disposition, featuring $\mathrm{H}-3$ as a br s or as a dd $(J=2.5,2.5 \mathrm{~Hz})$. Compounds 12 and 15-17 belong to the $\beta$ series, with the substituent at C-3 in $\beta$ disposition, as corroborated the well differentiated coupling constants of $\mathrm{H}-3$ $(\approx 5$ and $10 \mathrm{~Hz}$ ).

Also, in 18 the NOEs observed between $\mathrm{H}-11$ and $\mathrm{H}_{3}-18$ and $\mathrm{H}_{3}-19$ indicate that the hydroxyl group at C-11 is located equatorial, on the opposite side of the molecule of Me-18 and Me-19.

\section{Absolute configuration of the steroidal nucleus}

Derivatization of 14 with $(R)$ - and $(S)$ - $\alpha$-methoxy- $\alpha$-phenylacetic acids (MPA) produced the diesters 14a and 14b. NMR analysis of the $\Delta \delta$ values of the protons influenced by the MPA group at C-3 of 14a and 14b gave clear evidence to assign the absolute configuration at C-3 as $S$, Table 5 .

\section{Absolute configuration of the side chain}

The absolute configuration of C-22 of compound 13 was established by derivatization with $(R)$ - and (S)-MPA which produced diesters 13a and 13b. NMR analysis of the $\Delta \delta$ values of the protons influenced by the MPA group at C-22 of 13a and 13b gave clear evidence to assign the absolute configuration at $\mathrm{C}-22$ as $S$, Table 6. The observed NOEs between $\mathrm{H}_{3}-18$ and $\mathrm{H}-20$ indicate a $\beta$ disposition for the side chain. Also, NOEs observed between $\mathrm{H}-22$ and $\mathrm{H}_{2}-16$ and between $\mathrm{H}_{3}-21$ and $\mathrm{H}$ $12 \beta$ indicated $\mathrm{C}-21$ must be in $\alpha$ disposition, therefore, considering that the absolute configuration at C-22 has been established as $S$, the absolute configuration of C-20 must be $S$. Based on these results, and considering that the 18 new steroids were isolated from the same organism, we can deduce the absolute configuration of the 18 steroids as shown on Fig. 2 .

Studies on the biosynthesis origin of marine sterols are scarce, ${ }^{\mathbf{1 1}}$ and they are complicated by the fact that several sources contribute, for example, sterol absorption produced by

Table $5{ }^{1} \mathrm{H}$ NMR $\Delta \delta\left(\delta_{R}-\delta_{S}\right)$ values $\left(\mathrm{CDCl}_{3}, \mathrm{ppm}\right.$, recorded at 500 $\mathrm{MHz}$ ) of the MPA esters $14 \mathrm{a}$ and $14 \mathrm{~b}$

\begin{tabular}{llll}
\hline Pos. & $\delta_{R}$ & $\delta_{S}$ & $\Delta \delta$ \\
\hline $\mathrm{H}-2 \beta$ & 0.78 & 1.36 & -0.58 \\
$\mathrm{H}-2 \alpha$ & 1.32 & 1.87 & -0.55 \\
$\mathrm{H}-4 \beta$ & 1.85 & 1.77 & +0.08 \\
$\mathrm{H}-4 \alpha$ & 1.58 & 1.48 & +0.1 \\
$\mathrm{H}-6$ & 4.58 & 4.53 & +0.05
\end{tabular}

Table $6{ }^{1} \mathrm{H}$ NMR $\Delta \delta\left(\delta_{R}-\delta_{S}\right)$ values $\left(\mathrm{CDCl}_{3}, \mathrm{ppm}\right.$, recorded at 500 $\mathrm{MHz}$ ) of the MPA esters $13 \mathrm{a}$ and $13 \mathrm{~b}$

\begin{tabular}{llll}
\hline Pos. & $\delta_{R}$ & $\delta_{S}$ & $\Delta \delta$ \\
\hline $\mathrm{H}-17$ & 0.98 & 0.94 & +0.04 \\
$\mathrm{H}_{3}-18$ & 0.53 & 0.18 & +0.35 \\
$\mathrm{H}-20$ & 1.45 & 1.28 & +0.17 \\
$\mathrm{H}_{3}-21$ & 0.92 & 0.72 & +0.20 \\
$\mathrm{H}-23 \mathrm{a}$ & 1.36 & 1.58 & -0.22 \\
$\mathrm{H}-23 \mathrm{~b}$ & 1.24 & 1.40 & -0.16 \\
$\mathrm{H}-25$ & 1.32 & 1.42 & -0.10 \\
$\mathrm{H}_{3}-26$ & 0.68 & 0.86 & -0.18 \\
$\mathrm{H}_{3}-27$ & 0.71 & 0.86 &
\end{tabular}

symbiotic organisms, assimilation or modification of sterols obtained from nutrition and biosynthesis de novo. ${ }^{12}$

In this study, the octocoral yielded compounds 1-18, and they are a good example of how nature generates structural complexity and biological activity, by diversifying oxidation processes from a precursor of low oxidation state. It appears that these compounds are linked together by a network of enzymatic oxygenation processes around the active sites of normal nuclei $3 \beta$-hydroxy- $\Delta^{5}$ (ring A/B system) and side chains of eight carbon atoms, to give $3 \beta, 5 \alpha, 6 \beta-; 3 \beta, 5 \alpha, 6 \beta-19-o x y-$ and also isomerization to $3 \alpha, 5 \alpha, 6 \beta-19$-oxy-sterols derivatives. $\Delta^{5}$ activation of the allylic position is an important way of providing polar steroids, and it has been argued that its biosynthesis in octocorals follows a different path to the sponges. ${ }^{6}$ While in sponges the presence of unsaturation to spread oxidation in cascade toward the other end (rings C/D system) is necessary, their biogenesis in soft corals seems to run independently of the unsaturation activation pathway. Indeed, even when the $\Delta^{5}$ is saturated or oxidized to epoxide or diols, oxidation of the rest of the carbons in the nucleus can proceed further.

Compound 17 features a previously known cholestane nuclear oxidation pattern with several examples of compounds found in corals among other organisms. ${ }^{\mathbf{1 3 , 1 4}}$ Oxisterols 1-8 and 12-14 feature a nuclear oxidation pattern only found in five compounds previously isolated from corals, ${ }^{10,15-21}$ and the same occurs with compounds 16 and 18, whose nuclear oxidation models have been described once for each case and both isolated from octocorals. ${ }^{22-24} 15$ is the first example of a steroid with this oxidation pattern on the steroidal nucleus suggesting that these specific compounds are only produced by certain species, which may represent a chemical signature to these.

\section{Antimicrobial activity}

The antimicrobial activities of the steroids $\mathbf{1 ,}, \mathbf{3}, \mathbf{4}, \mathbf{6 ,} \mathbf{8 - 1 0}$ and 13-15 were tested in vitro by the broth macrodilution method. Unfortunately, almost all tested compounds were found to be practically inactive against all bacterial strains under study with the exception of compounds $\mathbf{1 4}$ and $\mathbf{1 5}$ which showed weak activity. Compound $\mathbf{1 4}$ displayed weak antibacterial activity against Gram + Bacillus cereus and Staphylococcus aureus and Gram - Klebsiella pneumoniae with MIC values ranging from 25 to $50 \mu \mathrm{g} \mathrm{mL} \mathrm{m}^{-1}$ on the three strains. Compound 15 showed activity against $K$. pneumoniae with a MIC $\geq 50 \mu \mathrm{g} \mathrm{mL}{ }^{-1}$. 


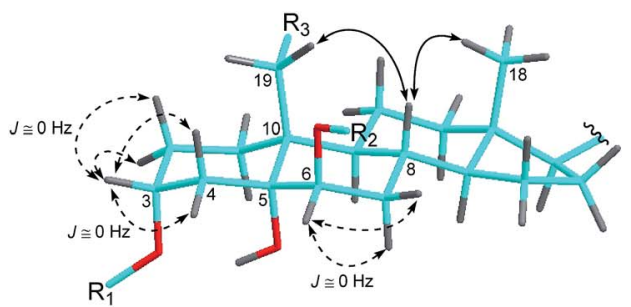

1, 3, 4, 5: $\mathrm{R}_{1}=\mathrm{OH}, \mathrm{R}_{2}=\mathrm{OAc}, \mathrm{R}_{3}=\mathrm{OH}$

2, 8: $\mathrm{R}_{1}=\mathrm{OAc}, \mathrm{R}_{2}=\mathrm{OAc}, \mathrm{R}_{3}=\mathrm{OH}$

6: $\mathrm{R}_{1}=\mathrm{OAc}, \mathrm{R}_{2}=\mathrm{OH}, \mathrm{R}_{3}=\mathrm{OH}$

7: $\mathrm{R}_{1}=\mathrm{OAc}, \mathrm{R}_{2}=\mathrm{OH}, \mathrm{R}_{3}=\mathrm{OAc}$

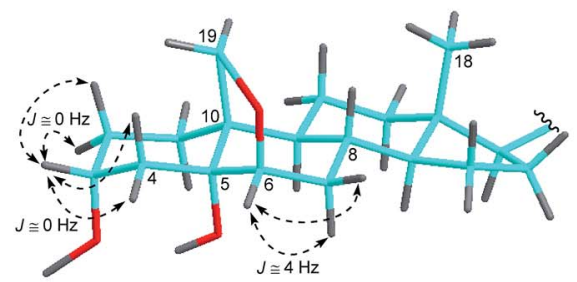

$9,10,11$

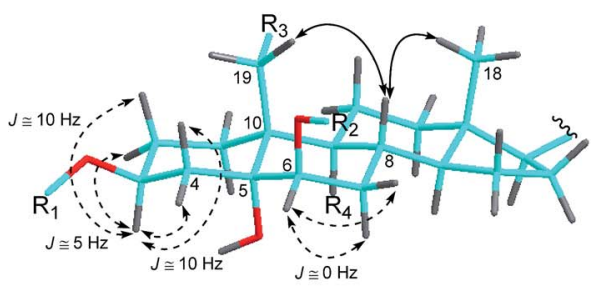

12, 14: $\mathrm{R}_{1}=\mathrm{OH}, \mathrm{R}_{2}=\mathrm{OAc}, \mathrm{R}_{3}=\mathrm{OH}, \mathrm{R}_{4}=\mathrm{H}$

13: $R_{1}=O A c, R_{2}=O A c, R_{3}=O H, R_{4}=H$

15: $\mathrm{R}_{1}=\mathrm{OH}, \mathrm{R}_{2}=\mathrm{OAc}, \mathrm{R}_{3}=\mathrm{OH}, \mathrm{R}_{4}=\mathrm{OH}$

16: $\mathrm{R}_{1}=\mathrm{OH}, \mathrm{R}_{2}=\mathrm{OH} \mathrm{R}_{3}=\mathrm{H}, \mathrm{R}_{4}=\mathrm{OH}$

17: $\mathrm{R}_{1}=\mathrm{OH}, \mathrm{R}_{2}=\mathrm{OAc}, \mathrm{R}_{3}=\mathrm{H}, \mathrm{R}_{4}=\mathrm{H}$

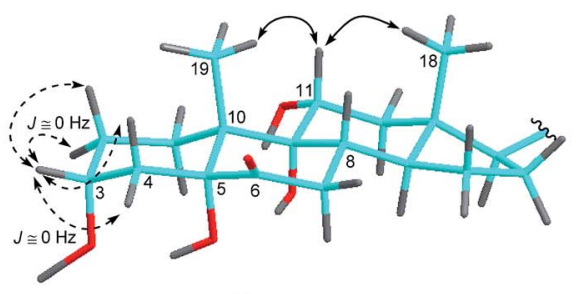

18

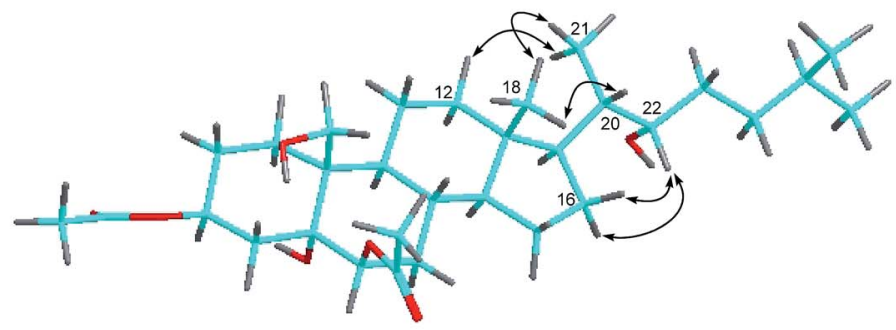

13

NOESY $\neg$ Coupling constants

Fig. 2 Selected NOEs and coupling constants for compounds 1-18.

\section{Antileishmanial effect}

Antileishmanial effect of steroids 1-5, 7-11 and 14-18 was determined against Leishmania infantum promastigotes. Initial screening yielded highly variable results. 4, 5, 7-9, 11, 16-18 were the least active compounds ( $\leq 55 \%$ inhibition) whereas 14 reduced the multiplication of promastigotes by more than $95 \%$, at $100 \mu \mathrm{M}$ and compounds $\mathbf{1}$ and 2 reduced the multiplication of promastigotes by more than $70 \%$ at $100 \mu \mathrm{M}$. Compounds 3 , 10 and 15 reduced the multiplication of promastigotes by 63, 56 and $60 \%$, respectively at $100 \mu \mathrm{M}$ (Table 7). Dose-response curves of the most active compounds showed $\mathrm{IC}_{50}$ values of 59.5 and $50.7 \mu \mathrm{M}$ for 1 and 14 , respectively.

Toxicity for mammalian cells (primary mouse peritoneal macrophages) (M $\phi$ ) was explored for 1, 2, 3, 10, 14 and 15 using MTT method. No clear dose-response curve was obtained with the concentrations used and wide variations were found. Thus $50 \mu \mathrm{M}$ of 2 reduced $\mathrm{M} \phi$ viability by $c a$. $50 \%$ whereas the same concentration of $\mathbf{1 0}$ induced a mere $12 \%$ reduction in $\mathrm{M} \phi$ viability. Interestingly one of the compounds with the highest antileishmanial activity $\mathbf{1 4}$ did not provoke a 50\% reduction with $400 \mu \mathrm{M}$. The high $\mathrm{IC}_{50}(>50 \mu \mathrm{M})$ found for compound 14 against Leishmania promastigotes compared to that of the positive control, amphotericin $\mathrm{B}\left(\mathrm{IC}_{50}=0.1 \mu \mathrm{M}\right)$, probably excludes this steroid for antileishmanial monotherapy. However, the apparent reduced toxicity for mammalian cells suggests the interest of evaluating the antileishmanial efficacy of 14 against intracellular amastigotes and its potential synergistic effect with other well established antileishmanial drugs.

The relative activity of $\mathbf{1}$ and $\mathbf{3}$ compared with that of $\mathbf{1 4}$ indicates that compounds belonging to the $\beta$ series may present better antileishmanial effect (Fig. 3). Compounds 1, 3 and 4, belong to $\alpha$ series and they possess the same functional groups and configurations at C-3, C-5, C-6 and C-19 but differ at C-22. From the analysis of their chemical structures it can be deduced that the presence of a hydroxyl group at C-22 increases the antileishmanial effect in this type of compounds, for 
Table 7 Antileishmanial effect of compounds 1-5, 7-11 and 14-18 in Leishmania infantum promastigotes

\begin{tabular}{lrrr}
\hline \multicolumn{2}{l}{ \% inhibition } \\
\cline { 2 - 4 } & \multicolumn{2}{l}{ Concentration $(\mu \mathrm{M})$} & \\
\cline { 2 - 4 } Compd & $10 \mu \mathrm{M}$ & $50 \mu \mathrm{M}$ & $100 \mu \mathrm{M}$ \\
\hline $\mathbf{1}$ & $\mathbf{1 0 . 7}$ & 27.2 & 72.6 \\
$\mathbf{2}$ & $\mathbf{2 5 . 8}$ & $\mathbf{4 8 . 5}$ & 72.6 \\
$\mathbf{3}$ & 0.0 & 25.4 & 63.6 \\
$\mathbf{4}$ & 0.0 & 0.0 & 39.1 \\
$\mathbf{5}$ & 3.3 & 3.1 & 53.9 \\
7 & 0.0 & 22.6 & 32.3 \\
$\mathbf{8}$ & 1.5 & 9.4 & 42.1 \\
$\mathbf{9}$ & 16.6 & 4.3 & 7.8 \\
$\mathbf{1 0}$ & 5.2 & 47.1 & 56.4 \\
$\mathbf{1 1}$ & 0.0 & 23.7 & 40.0 \\
$\mathbf{1 4}$ & $\mathbf{9 . 6}$ & 70.9 & 96.3 \\
$\mathbf{1 6}$ & 0.0 & 34.7 & 62.2 \\
$\mathbf{1 7}$ & 0.0 & 0.0 & 32.5 \\
$\mathbf{1 8}$ & 0.0 & 0.0 & 43.4 \\
& 0.0 & 55.4 & 31.1
\end{tabular}

instance 1. Moreover, it seems that the formation of the cyclic ether between C-6 and C-19 reduces the activity (tandem 1/9). From comparison of $\mathbf{1 4}$ and $\mathbf{1 5}$ it can be deduced that hydroxylation of C-9 reduces the antileishmanial activity.

\section{Experimental}

\section{General experimental procedures}

Optical rotations were measured on a Perkin-Elmer model 343 Plus polarimeter using a Na lamp at $20{ }^{\circ} \mathrm{C}$. IR spectra were recorded on a Perkin-Elmer 1650/FTIR spectrometer. ${ }^{1} \mathrm{H}$ NMR and ${ }^{13} \mathrm{C}$ NMR, HSQC, HMBC and COSY spectra were measured employing a Bruker AMX 500 instrument operating at $500 \mathrm{MHz}$ for ${ }^{1} \mathrm{H}$ NMR and at $125 \mathrm{MHz}$ for ${ }^{13} \mathrm{C}$ NMR. All ${ }^{13} \mathrm{C}$ and ${ }^{1} \mathrm{H}$ NMR spectra were internally referenced to the residual solvent signal $\left(\mathrm{CDCl}_{3}: \delta_{\mathrm{C}} 77.0 \mathrm{ppm}, \delta_{\mathrm{H}} 7.25 \mathrm{ppm}\right)$. Two-dimensional NMR spectra were obtained using the standard Bruker software. EIMS and HRMS data were taken on a Micromass Autospec spectrometer. ESIMS and HRESI MS (positive-ion mode) data were taken on a Micromass LCT Premier XE. The gel filtration column (Sephadex LH-20) used hexane $/ \mathrm{CH}_{2} \mathrm{Cl}_{2} / \mathrm{MeOH}(3: 1: 1)$ as eluent. HPLC separations were performed on an Agilent 1200 Series Quaternary LC system using a Jaigel-Sil-043-10 semipreparative column $(10 \mu \mathrm{m}, 20 \times 250 \mathrm{~mm})$ eluted with hexane/ EtOAc mixtures. The spray reagent for TLC was $\mathrm{H}_{2} \mathrm{SO}_{4} / \mathrm{H}_{2} \mathrm{O}$ / AcOH $(1: 4: 20)$.

\section{Biological material}

Gorgonia sp. was collected by SCUBA diving off Aleta Island (Panama) at $-15 \mathrm{~m}$.

\section{Extraction}

Air-dried samples (499 g) were extracted with acetone at room temperature, and were concentrated to give a dark residue (8.35 $\mathrm{g})$.

\section{Purification}

Crude extract was fractionated by reversed-phase C-18 silica flash chromatography using step-gradient elution $\left(100 \% \mathrm{H}_{2} \mathrm{O}\right.$ to $100 \% \mathrm{MeOH})$. Fraction eluted with $\mathrm{MeOH}(100 \%)$ was subjected to a gel filtration chromatography (Sephadex LH-20) followed by HPLC to afford 1 (7.0 mg), 2 (3.2 mg), 3 (9.9 mg), 4 (1.8 mg), 5 (20.6 mg), 6 (3.8 mg), 7 (2.4 mg), 8 (59.6 mg), 9 (0.8 mg), 10 (3.0
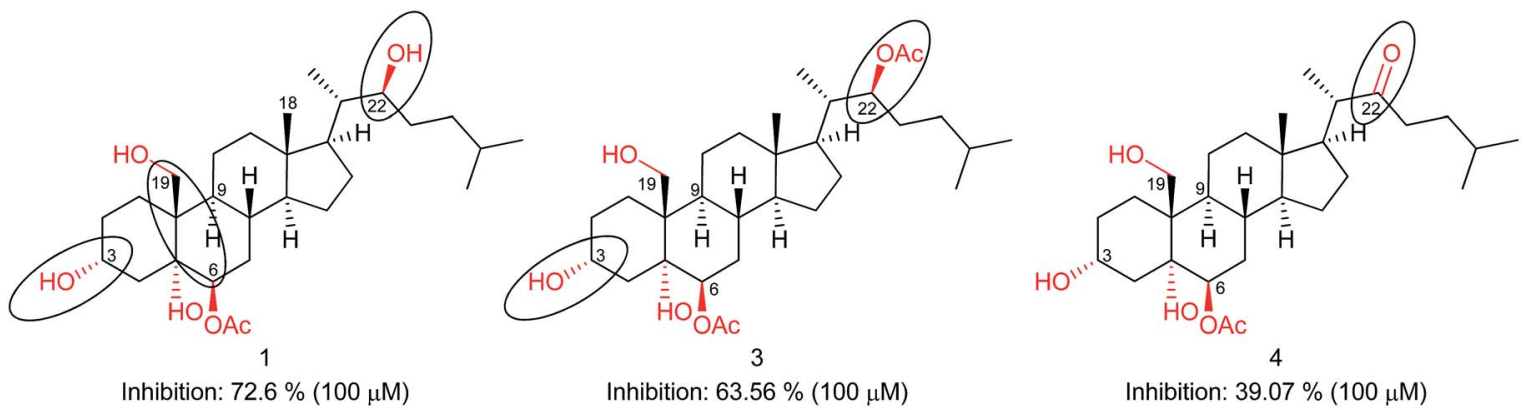

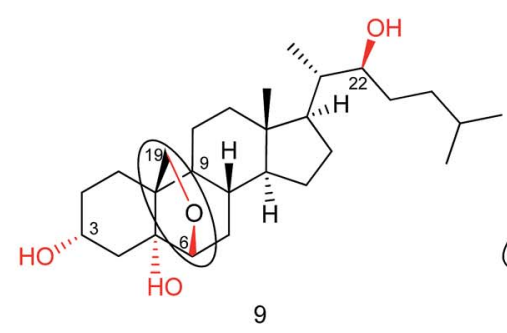

Inhibition: $7.68 \%(100 \mu \mathrm{M})$

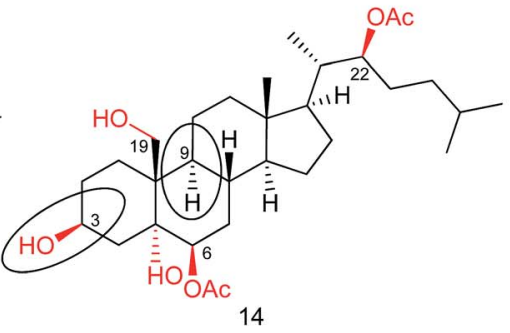

Inhibition: $96.26 \%(100 \mu \mathrm{M})$

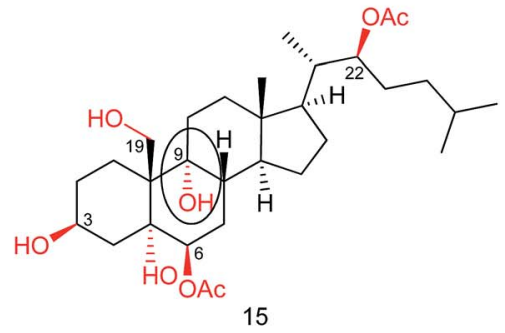

Inhibition: $66.23 \%(100 \mu \mathrm{M})$

Fig. 3 Structure and antileishmanial effect of some of the isolated compounds. 
mg), 11 (0.8 mg), 12 (7.0 mg), 13 (7.3 mg), 14 (34.7 mg), 15 (4.8 $\mathrm{mg}), \mathbf{1 6}(0.4 \mathrm{mg}), \mathbf{1 7}(3.0 \mathrm{mg})$ and $18(2.0 \mathrm{mg})$.

\section{Characterisation of compounds}

Compound 1. Isolated as an amorphous solid; $[\alpha]_{\mathrm{D}}^{20}-49$ (c $0.35, \mathrm{CH}_{2} \mathrm{Cl}_{2}$ ); IR (film) $\nu_{\max } 3420,2944,1716,1258,1031$ $\mathrm{cm}^{-1}$; EIMS $\mathrm{m} / \mathrm{z} 494[\mathrm{M}]^{+}$(55), $476\left[\mathrm{M}-\mathrm{H}_{2} \mathrm{O}\right]^{+}$(75), $458[\mathrm{M}-$ $\left.2 \mathrm{H}_{2} \mathrm{O}\right]^{+}(25), 440\left[\mathrm{M}-3 \mathrm{H}_{2} \mathrm{O}\right]^{+}(13), 426\left[\mathrm{M}-\mathrm{CH}_{3} \mathrm{OH}-2 \mathrm{H}_{2} \mathrm{O}\right]^{+}$ (22); HREIMS [M] $]^{+} \mathrm{m} / z 494.3622$ (calcd for $\mathrm{C}_{29} \mathrm{H}_{50} \mathrm{O}_{6}, 494.3607$ ), 476.3499 (calcd for $\mathrm{C}_{29} \mathrm{H}_{48} \mathrm{O}_{5}, 476.3502$ ), 458.3409 (calcd for $\mathrm{C}_{29} \mathrm{H}_{46} \mathrm{O}_{4}, 458.3396$ ), 440.3307 (calcd for $\mathrm{C}_{29} \mathrm{H}_{44} \mathrm{O}_{3}, 440.3290$ ), 426.3134 (calcd for $\mathrm{C}_{28} \mathrm{H}_{42} \mathrm{O}_{3}, 426.3134$ ); ${ }^{13} \mathrm{C}$ and ${ }^{1} \mathrm{H}$ NMR see Tables 1 and 2.

Compound 2. Isolated as an amorphous solid; $[\alpha]_{\mathrm{D}}^{20}+58$ (c 0.12, $\mathrm{CH}_{2} \mathrm{Cl}_{2}$ ); IR (film) $\nu_{\max } 3486,2940,1740,1731,1241$, $1031 \mathrm{~cm}^{-1}$; EIMS $\mathrm{m} / z 536[\mathrm{M}]^{+}(14), 458\left[\mathrm{M}-\mathrm{AcOH}-\mathrm{H}_{2} \mathrm{O}\right]^{+}$ (58), $367\left[\mathrm{M}-2 \mathrm{AcOH}-\mathrm{CH}_{2} \mathrm{OH}-\mathrm{H}_{2} \mathrm{O}\right]^{+}$(14); HREIMS [M] $]^{+} \mathrm{m} / \mathrm{z}$ 536.3731 (calcd for $\mathrm{C}_{31} \mathrm{H}_{52} \mathrm{O}_{7}, 536.3713$ ), 458.3418 (calcd for $\mathrm{C}_{29} \mathrm{H}_{46} \mathrm{O}_{4}$, 458.3396), 367.3002 (calcd for $\mathrm{C}_{26} \mathrm{H}_{39} \mathrm{O}$, 367.3001); ${ }^{13} \mathrm{C}$ and ${ }^{1} \mathrm{H}$ NMR see Tables 1 and 2.

Compound 3. Isolated as an amorphous solid; $[\alpha]_{\mathrm{D}}^{20}-27$ (c 0.46, $\mathrm{CH}_{2} \mathrm{Cl}_{2}$ ); IR (film) $\nu_{\max } 3420,2947,1732,1716,1245$, $1031 \mathrm{~cm}^{-1}$; EIMS $m / z 536[\mathrm{M}]^{+}(10), 504\left[\mathrm{M}-\mathrm{CH}_{3} \mathrm{OH}\right]^{+}(20), 458$ $\left[\mathrm{M}-\mathrm{AcOH}-\mathrm{H}_{2} \mathrm{O}\right]^{+}(39), 440\left[\mathrm{M}-\mathrm{AcOH}-2 \mathrm{H}_{2} \mathrm{O}\right]^{+}(27), 409[\mathrm{M}$ $\left.-\mathrm{AcOH}-\mathrm{CH}_{2} \mathrm{OH}-2 \mathrm{H}_{2} \mathrm{O}\right]^{+}(30), 398\left[\mathrm{M}-2 \mathrm{AcOH}-\mathrm{H}_{2} \mathrm{O}\right]^{+}(25)$, $380\left[\mathrm{M}-2 \mathrm{AcOH}-2 \mathrm{H}_{2} \mathrm{O}\right]^{+}(23), 367\left[\mathrm{M}-2 \mathrm{AcOH}-\mathrm{CH}_{2} \mathrm{OH}-\right.$ $\left.\mathrm{H}_{2} \mathrm{O}\right]^{+}$(15); HREIMS [M] ${ }^{+} \mathrm{m} / \mathrm{z} 536.3688$ (calcd for $\mathrm{C}_{31} \mathrm{H}_{52} \mathrm{O}_{7}$, 536.3713), 504.3470 (calcd for $\mathrm{C}_{30} \mathrm{H}_{48} \mathrm{O}_{6}, 504.3451$ ), 458.3386 (calcd for $\mathrm{C}_{29} \mathrm{H}_{46} \mathrm{O}_{4}, 458.3396$ ), 440.3300 (calcd for $\mathrm{C}_{29} \mathrm{H}_{44} \mathrm{O}_{3}$, 440.3290), 409.3123 (calcd for $\mathrm{C}_{28} \mathrm{H}_{41} \mathrm{O}_{2}, 409.3107$ ), 398.3173 (calcd for $\mathrm{C}_{27} \mathrm{H}_{42} \mathrm{O}_{2}, 398.3185$ ), 380.3064 (calcd for $\mathrm{C}_{27} \mathrm{H}_{40} \mathrm{O}$, 380.3079), 367.3015 (calcd for $\mathrm{C}_{26} \mathrm{H}_{39} \mathrm{O}, 367.3001$ ); ${ }^{13} \mathrm{C}$ and ${ }^{1} \mathrm{H}$ NMR see Tables 1 and 2.

Compound 4. Isolated as an amorphous solid; $[\alpha]_{\mathrm{D}}^{20}+59$ (c $0.18, \mathrm{CH}_{2} \mathrm{Cl}_{2}$ ); IR (film) $\nu_{\max } 3420,2940,1732,1716,1241$ $\mathrm{cm}^{-1}$; EIMS $\mathrm{m} / \mathrm{z} 492[\mathrm{M}]^{+}$(59), $460\left[\mathrm{M}-\mathrm{CH}_{3} \mathrm{OH}\right]^{+}$(17); HREIMS $[\mathrm{M}]^{+} \mathrm{m} / \mathrm{z} 492.3434$ (calcd for $\mathrm{C}_{29} \mathrm{H}_{48} \mathrm{O}_{6}, 492.3451$ ), 460.3188 (calcd for $\mathrm{C}_{28} \mathrm{H}_{44} \mathrm{O}_{5}, 460.3189$ ); ${ }^{13} \mathrm{C}$ and ${ }^{1} \mathrm{H}$ NMR see Tables 1 and 2 .

Compound 5. Isolated as an amorphous solid; $[\alpha]_{\mathrm{D}}^{20}-34$ (c 0.68, $\mathrm{CH}_{2} \mathrm{Cl}_{2}$ ); IR (film) $\nu_{\max } 3412,2944,1731,1714,1246$ $\mathrm{cm}^{-1}$; EIMS $m / z 552[\mathrm{M}]^{+}(4), 521\left[\mathrm{M}-\mathrm{CH}_{2} \mathrm{OH}\right]^{+}(9), 517[\mathrm{M}-$ $\left.\mathrm{H}_{2} \mathrm{O}-\mathrm{OH}\right]^{+}(8), 492\left[\mathrm{M}-\mathrm{C}_{3} \mathrm{H}_{8} \mathrm{O}\right]^{+}(54), 485\left[\mathrm{M}-\mathrm{CH}_{2} \mathrm{OH}-\right.$ $\left.2 \mathrm{H}_{2} \mathrm{O}\right]^{+}$(10); HREIMS [M] $]^{+} \mathrm{m} / \mathrm{z} 552.3671$ (calcd for $\mathrm{C}_{31} \mathrm{H}_{52} \mathrm{O}_{8}$, 552.3662), 521.3486 (calcd for $\mathrm{C}_{30} \mathrm{H}_{49} \mathrm{O}_{7}, 521.3478$ ), 517.3537 (calcd for $\mathrm{C}_{31} \mathrm{H}_{49} \mathrm{O}_{6}, 517.3529$ ), 492.3091 (calcd for $\mathrm{C}_{28} \mathrm{H}_{44} \mathrm{O}_{7}$, 492.3087), 485.3281 (calcd for $\mathrm{C}_{30} \mathrm{H}_{45} \mathrm{O}_{5}, 485.3267$ ); ${ }^{13} \mathrm{C}$ and ${ }^{1} \mathrm{H}$ NMR see Tables 1 and 2.

Compound 6. Isolated as an amorphous solid; $[\alpha]_{\mathrm{D}}^{20}-24$ (c 0.28, $\mathrm{CH}_{2} \mathrm{Cl}_{2}$ ); IR (film) $\nu_{\max } 3412,2936,1732,1716,1258$ $\mathrm{cm}^{-1}$; EIMS $m / z 552[\mathrm{M}]^{+}(9), 534\left[\mathrm{M}-\mathrm{H}_{2} \mathrm{O}\right]^{+}(11), 516[\mathrm{M}-$ $\left.2 \mathrm{H}_{2} \mathrm{O}\right]^{+}(8), 502\left[\mathrm{M}-\mathrm{CH}_{3} \mathrm{OH}-\mathrm{H}_{2} \mathrm{O}\right]^{+}(10), 456[\mathrm{M}-\mathrm{AcOH}-$ $\left.2 \mathrm{H}_{2} \mathrm{O}\right]^{+}(80), 424\left[\mathrm{M}-\mathrm{AcOH}-\mathrm{CH}_{3} \mathrm{OH}-2 \mathrm{H}_{2} \mathrm{O}\right]^{+}(15), 414[\mathrm{M}-$ $\left.2 \mathrm{AcOH}-\mathrm{H}_{2} \mathrm{O}\right]^{+}$(22); HREIMS [M] ${ }^{+} \mathrm{m} / \mathrm{z} 552.3589$ (calcd for $\mathrm{C}_{31} \mathrm{H}_{52} \mathrm{O}_{8}, 552.3662$ ), 534.3571 (calcd for $\mathrm{C}_{31} \mathrm{H}_{50} \mathrm{O}_{7}, 534.3557$ ), 516.3438 (calcd for $\mathrm{C}_{31} \mathrm{H}_{48} \mathrm{O}_{6}, 516.3451$ ), 502.3311 (calcd for
$\mathrm{C}_{30} \mathrm{H}_{46} \mathrm{O}_{6}, 502.3294$ ), 456.3224 (calcd for $\mathrm{C}_{29} \mathrm{H}_{44} \mathrm{O}_{4}, 456.3240$ ), 424.2980 (calcd for $\mathrm{C}_{28} \mathrm{H}_{40} \mathrm{O}_{3}, 424.2977$ ), 414.3132 (calcd for $\left.\mathrm{C}_{27} \mathrm{H}_{42} \mathrm{O}_{3}, 414.3134\right) ;{ }^{13} \mathrm{C}$ and ${ }^{1} \mathrm{H}$ NMR see Tables 1 and 2.

Compound 7. Isolated as an amorphous solid; $[\alpha]_{\mathrm{D}}^{20}-173$ (c 0.05, $\mathrm{CH}_{2} \mathrm{Cl}_{2}$ ); IR (film) $\nu_{\max } 3442,2940,1729,1714,1376$, $1246 \mathrm{~cm}^{-1}$; EIMS $m / z 594[\mathrm{M}]^{+}(97), 456\left[\mathrm{M}-2 \mathrm{AcOH}-\mathrm{H}_{2} \mathrm{O}\right]^{+}$ (57), $346\left[\mathrm{M}-\mathrm{C}_{3} \mathrm{H}_{6} \mathrm{O}_{2}-2 \mathrm{AcOH}-3 \mathrm{H}_{2} \mathrm{O}\right]^{+}(10)$; HREIMS $[\mathrm{M}]^{+} \mathrm{m} /$ $z 594.3768$ (calcd for $\mathrm{C}_{33} \mathrm{H}_{54} \mathrm{O}_{9}, 594.3768$ ), 456.3232 (calcd for $\mathrm{C}_{29} \mathrm{H}_{44} \mathrm{O}_{4}, 456.3240$ ); 346.2674 (calcd for $\mathrm{C}_{26} \mathrm{H}_{34}, 346.2661$ ); ${ }^{13} \mathrm{C}$ and ${ }^{1} \mathrm{H}$ NMR see Tables 1 and 3 .

Compound 8. Isolated as an amorphous solid; $[\alpha]_{\mathrm{D}}^{20}-58$ (c 1.16, $\mathrm{CH}_{2} \mathrm{Cl}_{2}$ ); IR (film) $\nu_{\max } 3442,2951,1732,1716,1373$, $1246 \mathrm{~cm}^{-1}$; EIMS $\mathrm{m} / z 594[\mathrm{M}]^{+}(20), 456\left[\mathrm{M}-2 \mathrm{AcOH}-\mathrm{H}_{2} \mathrm{O}\right]^{+}$ (20), $425\left[\mathrm{M}-2 \mathrm{AcOH}-\mathrm{CH}_{2} \mathrm{OH}-\mathrm{H}_{2} \mathrm{O}\right]^{+}$(73); HREIMS [M] $]^{+} \mathrm{m} / \mathrm{z}$ 594.3769 (calcd for $\mathrm{C}_{33} \mathrm{H}_{54} \mathrm{O}_{9}, 594.3768$ ), 456.3235 (calcd for $\mathrm{C}_{29} \mathrm{H}_{44} \mathrm{O}_{4}, 456.3240$ ), 425.3036 (calcd for $\mathrm{C}_{28} \mathrm{H}_{41} \mathrm{O}_{3}, 425.3056$ ); ${ }^{13} \mathrm{C}$ and ${ }^{1} \mathrm{H}$ NMR see Tables 1 and 3.

Compound 9. Isolated as an amorphous solid; $[\alpha]_{\mathrm{D}}^{20}-107$ (c 0.18, $\mathrm{CH}_{2} \mathrm{Cl}_{2}$ ); IR (film) $\nu_{\max } 3416,2933,1245,1081 \mathrm{~cm}^{-1}$; EIMS $m / z 434[\mathrm{M}]^{+}(7), 416\left[\mathrm{M}-\mathrm{H}_{2} \mathrm{O}\right]^{+}(52), 398\left[\mathrm{M}-2 \mathrm{H}_{2} \mathrm{O}\right]^{+}$ (79), $384\left[\mathrm{M}-\mathrm{CH}_{3} \mathrm{OH}-\mathrm{H}_{2} \mathrm{O}\right]^{+}(2), 380\left[\mathrm{M}-3 \mathrm{H}_{2} \mathrm{O}\right]^{+}(9), 366[\mathrm{M}$ $\left.-\mathrm{CH}_{3} \mathrm{OH}-2 \mathrm{H}_{2} \mathrm{O}\right]^{+}(9), 348\left[\mathrm{M}-\mathrm{CH}_{3} \mathrm{OH}-3 \mathrm{H}_{2} \mathrm{O}\right]^{+}$(4); HREIMS $[\mathrm{M}]^{+} \mathrm{m} / \mathrm{z} 434.3389$ (calcd for $\mathrm{C}_{27} \mathrm{H}_{46} \mathrm{O}_{4}, 434.3396$ ), 416.3291 (calcd for $\mathrm{C}_{27} \mathrm{H}_{44} \mathrm{O}_{3}, 416.3290$ ), 398.3165 (calcd for $\mathrm{C}_{27} \mathrm{H}_{42} \mathrm{O}_{2}$, 398.3185), 384.3047 (calcd for a $\mathrm{C}_{26} \mathrm{H}_{40} \mathrm{O}_{2}, 384.3028$ ), 380.3097 (calcd for $\mathrm{C}_{27} \mathrm{H}_{40} \mathrm{O}, 380.3079$ ), 366.2921 (calcd for $\mathrm{C}_{26} \mathrm{H}_{38} \mathrm{O}$, 366.2923), 348.2805 (calcd for $\mathrm{C}_{26} \mathrm{H}_{36}, 348.2817$ ); ${ }^{13} \mathrm{C}$ and ${ }^{1} \mathrm{H}$ NMR see Tables 1 and 3.

Compound 10. Isolated as an amorphous solid; $[\alpha]_{\mathrm{D}}^{20}-50$ (c 0.14, $\mathrm{CH}_{2} \mathrm{Cl}_{2}$ ); IR (film) $\nu_{\max } 3416,2933,1731,1246,1022$ $\mathrm{cm}^{-1}$; EIMS m/z $416[\mathrm{M}-\mathrm{AcOH}]^{+}$(68), $349[\mathrm{M}-\mathrm{AcOH}-$ $\left.\mathrm{CH}_{2} \mathrm{OH}-2 \mathrm{H}_{2} \mathrm{O}\right]^{+}(20), 304\left[\mathrm{M}-\mathrm{C}_{10} \mathrm{H}_{20} \mathrm{O}_{2}\right]^{+}$(93); HRESIMS [M + $\mathrm{Na}]^{+} \mathrm{m} / \mathrm{z} 499.3386$ (calcd for $\mathrm{C}_{29} \mathrm{H}_{48} \mathrm{O}_{5} \mathrm{Na}, 499.3399$ ); ${ }^{13} \mathrm{C}$ and ${ }^{1} \mathrm{H}$ NMR see Tables 1 and 3.

Compound 11. Isolated as an amorphous solid; $[\alpha]_{\mathrm{D}}^{20}-300$ (c $0.08, \mathrm{CH}_{2} \mathrm{Cl}_{2}$ ); IR (film) $\nu_{\max } 3408,2933,1731,1248 \mathrm{~cm}^{-1}$; EIMS $m / z 492[\mathrm{M}]^{+}$(15), $474\left[\mathrm{M}-\mathrm{H}_{2} \mathrm{O}\right]^{+}$(7); HREIMS [M] ${ }^{+} \mathrm{m} / \mathrm{z}$ 492.3455 (calcd for $\mathrm{C}_{29} \mathrm{H}_{48} \mathrm{O}_{6}, 492.3451$ ), 447.3354 (calcd for $\left.\mathrm{C}_{29} \mathrm{H}_{46} \mathrm{O}_{5}, 474.3345\right) ;{ }^{13} \mathrm{C}$ and ${ }^{1} \mathrm{H}$ NMR see Tables 1 and 3.

Compound 12. Isolated as an amorphous solid; $[\alpha]_{\mathrm{D}}^{20}-73$ (c $0.35, \mathrm{CH}_{2} \mathrm{Cl}_{2}$ ); IR (film) $\nu_{\max } 3408,2947,1721,1261,1031$ $\mathrm{cm}^{-1}$; EIMS $\mathrm{m} / z 494[\mathrm{M}]^{+}(91), 476\left[\mathrm{M}-\mathrm{H}_{2} \mathrm{O}\right]^{+}(41), 458[\mathrm{M}-$ $\left.2 \mathrm{H}_{2} \mathrm{O}\right]^{+}(56), 440\left[\mathrm{M}-3 \mathrm{H}_{2} \mathrm{O}\right]^{+}(85), 385\left[\mathrm{M}-\mathrm{AcOH}-\mathrm{CH}_{2} \mathrm{OH}-\right.$ $\left.\mathrm{H}_{2} \mathrm{O}\right]^{+}(7), 366\left[\mathrm{M}-\mathrm{AcOH}-\mathrm{CH}_{3} \mathrm{OH}-2 \mathrm{H}_{2} \mathrm{O}\right]^{+}(6)$; HREIMS $[\mathrm{M}]^{+}$ $\mathrm{m} / \mathrm{z} 494.3627$ (calcd for $\mathrm{C}_{29} \mathrm{H}_{50} \mathrm{O}_{6}, 494.3607$ ), 476.3487 (calcd for $\mathrm{C}_{29} \mathrm{H}_{48} \mathrm{O}_{5}, 476.3502$ ), 458.3406 (calcd for $\mathrm{C}_{29} \mathrm{H}_{46} \mathrm{O}_{4}, 458.3396$ ), 440.3275 (calcd for $\mathrm{C}_{29} \mathrm{H}_{44} \mathrm{O}_{3}, 440.3290$ ), 385.3110 (calcd for $\mathrm{C}_{26} \mathrm{H}_{41} \mathrm{O}_{2}, 385.3107$ ), 366.2918 (calcd for $\mathrm{C}_{26} \mathrm{H}_{38} \mathrm{O}, 366.2923$ ); ${ }^{13} \mathrm{C}$ and ${ }^{1} \mathrm{H}$ NMR see Tables 1 and 3.

Compound 13. Isolated as an amorphous solid; $[\alpha]_{\mathrm{D}}^{20}-50$ (c $0.34, \mathrm{CH}_{2} \mathrm{Cl}_{2}$ ); IR (film) $\nu_{\max } 3442,2947,1721,1259,1031$ $\mathrm{cm}^{-1}$; EIMS $m / z 536[\mathrm{M}]^{+}(4), 458\left[\mathrm{M}-\mathrm{AcOH}-\mathrm{H}_{2} \mathrm{O}\right]^{+}(8), 398[\mathrm{M}$ $\left.-2 \mathrm{AcOH}-\mathrm{H}_{2} \mathrm{O}\right]^{+}(2), 367\left[\mathrm{M}-2 \mathrm{AcOH}-\mathrm{CH}_{2} \mathrm{OH}-\mathrm{H}_{2} \mathrm{O}\right]^{+}(23)$; HREIMS [M] ${ }^{+} \mathrm{m} / \mathrm{z} 536.3699$ (calcd for $\mathrm{C}_{31} \mathrm{H}_{52} \mathrm{O}_{7}, 536.3713$ ), 458.3406 (calcd for $\mathrm{C}_{29} \mathrm{H}_{46} \mathrm{O}_{4}, 458.3396$ ), 398.3183 (calcd for $\mathrm{C}_{27} \mathrm{H}_{42} \mathrm{O}_{2}, 398.3185$ ), 367.2985 (calcd for $\mathrm{C}_{26} \mathrm{H}_{39} \mathrm{O}, 367.3001$ ); ${ }^{13} \mathrm{C}$ and ${ }^{1} \mathrm{H}$ NMR see Tables 1 and 4. 
Compound 14. Isolated as an amorphous solid; $[\alpha]_{\mathrm{D}}^{20}-54(c$ 0.63, $\mathrm{CH}_{2} \mathrm{Cl}_{2}$ ); IR (film) $\nu_{\max } 3412,2955,1732,1716,1373,1245$, $1033 \mathrm{~cm}^{-1}$; EIMS $m / z 536[\mathrm{M}]^{+}(2), 500\left[\mathrm{M}-2 \mathrm{H}_{2} \mathrm{O}\right]^{+}(6), 458[\mathrm{M}-$ $\left.\mathrm{AcOH}-\mathrm{H}_{2} \mathrm{O}\right]^{+}$(29); HRESMS $[\mathrm{M}]^{+} \mathrm{m} / z 536.3734$ (calcd for $\mathrm{C}_{31} \mathrm{H}_{52} \mathrm{O}_{7}, 536.3713$ ), 500.3505 (calcd for $\mathrm{C}_{31} \mathrm{H}_{48} \mathrm{O}_{5}, 500.3502$ ), 458.3403 (calcd for $\mathrm{C}_{29} \mathrm{H}_{46} \mathrm{O}_{4}, 458.3396$ ); ${ }^{13} \mathrm{C}$ and ${ }^{1} \mathrm{H}$ NMR see Tables 1 and 4 .

Compound 15. Isolated as an amorphous solid; $[\alpha]_{\mathrm{D}}^{20}-91$ (c $0.48, \mathrm{CH}_{2} \mathrm{Cl}_{2}$ ); IR (film) $\nu_{\max } 3394,1732,1718,1245,1035$ $\mathrm{cm}^{-1}$; EIMS $m / z 552[\mathrm{M}]^{+}(24), 534\left[\mathrm{M}-\mathrm{H}_{2} \mathrm{O}\right]^{+}(17), 516[\mathrm{M}-$ $\left.2 \mathrm{H}_{2} \mathrm{O}\right]^{+}(26), 502\left[\mathrm{M}-\mathrm{CH}_{3} \mathrm{OH}-\mathrm{H}_{2} \mathrm{O}\right]^{+}(30)$; HREIMS $[\mathrm{M}]^{+} \mathrm{m} / \mathrm{z}$ 552.3663 (calcd for $\mathrm{C}_{31} \mathrm{H}_{52} \mathrm{O}_{8}, 552.3662$ ), 534.3582 (calcd for $\mathrm{C}_{31} \mathrm{H}_{50} \mathrm{O}_{7}, 534.3557$ ), 516.3427 (calcd for $\mathrm{C}_{31} \mathrm{H}_{48} \mathrm{O}_{6}, 516.3451$ ), 502.3291 (calcd for $\mathrm{C}_{30} \mathrm{H}_{46} \mathrm{O}_{6}, 502.3294$ ); ${ }^{13} \mathrm{C}$ and ${ }^{1} \mathrm{H}$ NMR see Tables 1 and 4 .

Compound 16. Isolated as an amorphous solid; $[\alpha]_{\mathrm{D}}^{20}-240$ (c $0.04, \mathrm{CH}_{2} \mathrm{Cl}_{2}$ ); IR (film) $\nu_{\max } 3375,1731,1714,1243,1057$ $\mathrm{cm}^{-1}$; EIMS $m / z 494[\mathrm{M}]^{+}(18) 477[\mathrm{M}-\mathrm{OH}]^{+}$; HRESIMS [M] $]^{+} \mathrm{m} / \mathrm{z}$ 494.3580 (calcd for $\mathrm{C}_{29} \mathrm{H}_{50} \mathrm{O}_{6}, 494.3607$ ), 477.3597 (calcd for $\left.\mathrm{C}_{29} \mathrm{H}_{49} \mathrm{O}_{5}, 477.3580\right) ;{ }^{13} \mathrm{C}$ and ${ }^{1} \mathrm{H}$ NMR see Tables 1 and 4.

Compound 17. Isolated as an amorphous solid; $[\alpha]_{\mathrm{D}}^{20}-263$ (c $0.08, \mathrm{CH}_{2} \mathrm{Cl}_{2}$ ); IR (film) $\nu_{\max } 3531,1716,1243,1072 \mathrm{~cm}^{-1}$; EIMS $m / z 478[\mathrm{M}]^{+}(15), 400\left[\mathrm{M}-\mathrm{AcOH}-\mathrm{H}_{2} \mathrm{O}\right]^{+}$(31); HREIMS $[\mathrm{M}]^{+} \mathrm{m} / z 478.3641$ (calcd for $\mathrm{C}_{29} \mathrm{H}_{50} \mathrm{O}_{5}, 478.3658$ ), 400.3342 (calcd for $\mathrm{C}_{27} \mathrm{H}_{44} \mathrm{O}_{2}, 400.3341$ ); ${ }^{13} \mathrm{C}$ and ${ }^{1} \mathrm{H}$ NMR see Tables 1 and 4 .

Compound 18. Isolated as an amorphous solid; $[\alpha]_{\mathrm{D}}^{20}-209$ (c 0.14, $\mathrm{CH}_{2} \mathrm{Cl}_{2}$ ); IR (film) $\nu_{\max } 3438,2955,1732,1246 \mathrm{~cm}^{-1}$; EIMS $m / z 508[\mathrm{M}]^{+}(18), 490\left[\mathrm{M}-\mathrm{H}_{2} \mathrm{O}\right]^{+}(8)$; HREIMS $[\mathrm{M}]^{+} \mathrm{m} / \mathrm{z}$ 508.3397 (calcd for $\mathrm{C}_{29} \mathrm{H}_{48} \mathrm{O}_{7}, 508.3400$ ), 490.3300 (calcd for $\left.\mathrm{C}_{29} \mathrm{H}_{46} \mathrm{O}_{6}, 490.3294\right) ;{ }^{13} \mathrm{C}$ and ${ }^{1} \mathrm{H}$ NMR see Tables 1 and 4.

\section{$(R)$ - and (S)-MPA ester derivatives 14a and 14b}

A solution of compound $14\left(4.1 \mathrm{mg}, 7.6 \times 10^{-3} \mathrm{mmol}\right)$ in $0.5 \mathrm{~mL}$ of $\mathrm{CH}_{2} \mathrm{Cl}_{2}$ was treated with $N, N^{\prime}$-dicyclohexylcarbodiimide (13.5 $\left.\mathrm{mg}, 6.5 \times 10^{-2} \mathrm{mmol}\right)$, 4-dimethylaminopyridine $(6.7 \mathrm{mg}, 5.5 \times$ $\left.10^{-2} \mathrm{mmol}\right)$ and $(R)-\alpha$-methoxy- $\alpha$-phenylacetic acid $(12.7 \mathrm{mg}, 7.6$ $\times 10^{-2} \mathrm{mmol}$ ) and stirred at room temperature for $7 \mathrm{~h}$. After filtration, the reaction mixture was purified by silica gel chromatography (hexane-EtOAc $(1: 1))$ to give the $(R)$-MPA ester derivative 14a (6.0 mg, $7.1 \times 10^{-3} \mathrm{mmol}, 93.4 \%$ yield). The same experimental procedure was followed to obtain the $(S)$-MPA ester derivative $14 \mathbf{b}\left(6.7 \mathrm{mg}, 8.0 \times 10^{-3} \mathrm{mmol}, 81.3 \%\right.$ yield $)$.

\section{$(R)$ - and $(S)$-MPA ester derivatives $13 a$ and $13 b$}

A solution of compound $13\left(2.2 \mathrm{mg}, 4.1 \times 10^{-3} \mathrm{mmol}\right)$ in $0.5 \mathrm{~mL}$ of $\mathrm{CH}_{2} \mathrm{Cl}_{2}$ was treated with $N, N^{\prime}$-dicyclohexylcarbodiimide (7.3 $\mathrm{mg}, 3.5 \times 10^{-2} \mathrm{mmol}$ ), 4-dimethylaminopyridine (3.6 mg, $2.9 \times$ $\left.10^{-2} \mathrm{mmol}\right)$ and $(R)-\alpha$-methoxy- $\alpha$-phenylacetic acid $(6.8 \mathrm{mg}, 4.1$ $\times 10^{-2} \mathrm{mmol}$ ) and stirred at room temperature for $7 \mathrm{~h}$. After filtration, the reaction mixture was purified by silica gel chromatography (hexane-EtOAc $(1: 1)$ ) to give the $(R)$-MPA ester derivative $13 \mathrm{a}\left(1.9 \mathrm{mg}, 2.2 \times 10^{-3} \mathrm{mmol}, 53.7 \%\right.$ yield $)$. The same experimental procedure was followed to obtain the $(S)$-MPA ester derivative $13 \mathrm{~b}\left(2.1 \mathrm{mg}, 2.5 \times 10^{-3} \mathrm{mmol}, 61.6 \%\right.$ yield $)$.

\section{Antimicrobial activity}

Antimicrobial susceptibility test was performed by the broth macrodilution method (within the range $10-100 \mu \mathrm{g} \mathrm{mL} \mathrm{mL}^{-1}$ ) against the following strains obtained from the Spanish Collection of Type Cultures (CECT; Faculty of Biological Sciences, University of Valencia, Spain) and American Type Culture Collection (ATCC, USA): Staphylococcus aureus (ATCC 6538), Salmonella sp. (CECT 456), Klebsiella pneumoniae (ATCC 23357), Escherichia coli (ATCC 9637), Bacillus cereus (ATCC 21772), Proteus mirabilis (CECT 170), Enterococcus faecalis (ATCC 29212), and Candida albicans (ATCCMYA-2876) as described elsewhere. ${ }^{7}$ In the case of the yeast $C$. albicans the tryptic soy medium was replaced by the non-filament-inducing medium; YPD $[2 \%(\mathrm{w} / \mathrm{v})$ Bacto peptone, $1 \%(\mathrm{w} / \mathrm{v})$ yeast extract and $2 \%(\mathrm{w} /$ v) glucose]. The selected strains were chosen for key characteristics, in terms of ecology, physiology, metabolism and for ease of screening. Minimum inhibitory concentrations (MIC), was defined as the lowest substance concentration that completely inhibits microbial growth. MIC was determined from two independent experiments performed in triplicate for each concentration. All compounds were previously dissolved in DMSO.

\section{Antileishmanial effect}

Antileishmanial efficacy was determined using an isolate from Leishmania infantum (MCAN/ES/2001/UCM9) originally obtained from a naturally infected dog. Promastigotes were routinely cultured in RPMI 1640 medium (Lonza) with 10\% heat-inactivated fetal calf serum, $100 \mathrm{U} \mathrm{mL}^{-1}$ penicillin $+100 \mu \mathrm{g}$ $\mathrm{mL}^{-1}$ streptomycin $+1 \%$ L-glutamine and buffered with $20 \mathrm{mM}$ HEPES at $26{ }^{\circ} \mathrm{C}^{25}$ In the preliminary screening promastigotes $\left(1.25 \times 10^{6}\right.$ promastigotes per $\left.\mathrm{mL}\right)$ were exposed to $10 \mu \mathrm{M}$, $50 \mu \mathrm{M}$ and $100 \mu \mathrm{M}$ of each steroid. To determine the approximate $\mathrm{IC}_{50}$ selected molecules were tested at $10 \mu \mathrm{M}, 20 \mu \mathrm{M}$, $40 \mu \mathrm{M}, 60 \mu \mathrm{M}$ and $80 \mu \mathrm{M}$. Assays were performed in 96 well microtiter plates (Costar, Corning) at least in triplicate. Both positive (untreated promastigotes) and negative (promastigotes treated with $0.2 \mu \mathrm{M}$ amphotericin B) were included. Plates were incubated at $26{ }^{\circ} \mathrm{C}$ under $\mathrm{CO}_{2} /$ air (5\%/95\%) atmosphere. Leishmania proliferation was determined by Alamar Blue method and the intensity of fluorescence ( $\lambda 550$ excitation, $\lambda 590$ emission) measured. IC $_{50}$ was calculated by least squares fit. Macrophage $(\mathrm{M} \phi)$ viability was determined using MTT method. Briefly, peritoneal $\mathrm{M} \phi$ were obtained from $\mathrm{BAL} / \mathrm{c}$ mice and cultured $\left(3.75 \times 10^{6}\right.$ cells per mL) (RPMI medium) in 96 well flat-bottomed plates (Costar, Corning) in a final volume of 200 $\mu \mathrm{M}$ for $24 \mathrm{~h}$ under $\mathrm{CO}_{2}$ /air atmosphere. Cells were exposed to $12.5 \mu \mathrm{M}, 25 \mu \mathrm{M}, 50 \mu \mathrm{M}, 100 \mu \mathrm{M}, 200 \mu \mathrm{M}$ and $400 \mu \mathrm{M}$ from each molecule for $24 \mathrm{~h}$. Cellular viability was estimated with $\mathrm{MTT}^{26}$ and absorbance read at $570 \mathrm{~nm}$. Experiments were done in triplicate.

\section{Conclusions}

During the course of our chemical investigation we identified eighteen new oxysterols. These compounds bear the same 
cholestane nucleus but display a different oxidation pattern on the rings system. Among them, compound $\mathbf{1 5}$ is the first example of a steroid with this oxidation pattern on the steroidal nucleus.

The antileishmanial effect of the steroids tested was moderate against promastigotes. Toxicity for mammalian cells suggests the potential interest of the least toxic and most active molecule (14) in combination with other antileishmanial drugs.

\section{Acknowledgements}

This work was supported by the Ministerio de Ciencia e Innovación (BIO2007-61745 and SAF2009-0839). F. C. acknowledges financial support from Programa JAE-Pre (CSIC). ARDM acknowledges funding from IMBRAIN project (FP7-REGPOT2012-CT2012-31637-IMBRAIN). The STRI provided support and facilities. The Government of the Republic of Panama granted permission for the collection of the samples. COST Action CM1307 allowed the establishment of collaborative work.

\section{Notes and references}

1 G. J. Schroepfer Jr, Physiol. Rev., 2000, 80, 361-554.

2 B. A. Janowski, P. J. Willy, T. R. Devi, J. R. Falck and D. J. Mangelsdorf, Nature, 1996, 383, 728-731.

3 L. Xu, Z. Korade and N. A. Porter, J. Am. Chem. Soc., 2010, 132, 2222-2232.

4 M. V. D'Auria, L. Minale and R. Ricco, Chem. Rev., 1993, 93, 1839-1895.

5 V. A. Stonik, Russ. Chem. Rev., 2001, 70, 673-715.

6 N. S. Sarma, M. S. Krishna, S. G. Pasha, T. S. P. Rao, Y. Venkateswarlu and P. S. Parameswaran, Chem. Rev., 2009, 109, 2803-2828.

7 A. R. Díaz-Marrero, G. Porras, Z. Aragón, J. M. de la Rosa, E. Dorta, M. Cueto, L. D'Croz, J. Maté and J. Darias, J. Nat. Prod., 2011, 74, 292-295.

8 E. Dorta, A. R. Díaz-Marrero, M. Cueto, L. D'Croz, J. L. Maté, A. San-Martín and J. Darias, Tetrahedron Lett., 2004, 45, 915918.
9 M. Lorenzo, M. Cueto, L. D'Croz, J. L. Maté, A. San-Martín and J. Darias, Eur. J. Org. Chem., 2006, 582-585.

10 S.-Y. Cheng, C.-F. Dai and C.-Y. Duh, J. Nat. Prod., 2007, 70, 1449-1453.

11 M. J. Garson, Chem. Rev., 1993, 93, 1699-1733.

12 R. Thomas, Nat. Prod. Rep., 2004, 21, 224-248.

13 T.-F. Liu, X. Lu, H. Tang, M.-M. Zhang, P. Wang, P. Sun, Z.-Y. Liu, Z.-L. Wang, L. Li, Y.-C. Rui, T.-J. Li and W. Zhang, Steroids, 2013, 78, 108-114.

14 P. Wang, H. Tang, B.-S. Liu, T.-J. Li, P. Sun, W. Zhu, Y.-P. Luo and W. Zhang, Steroids, 2013, 78, 951-958.

15 C.-Y. Duh, S.-K. Wang, M.-J. Chu and J.-H. Sheu, J. Nat. Prod., 1998, 61, 1022-1024.

16 W. Zhang, W. K. Liu and C.-T. Che, Chem. Pharm. Bull., 2003, 51, 1009-1011.

17 A. A. H. El-Gamal, S.-K. Wang, C.-F. Dai and C.-Y. Duh, J. Nat. Prod., 2004, 67, 1455-1458.

18 R. Jia, Y.-W. Guo, E. Mollo, M. Gavagnin and G. Cimino, Helv. Chim. Acta, 2006, 89, 1330-1336.

19 X.-Y. Chai, J.-F. Sun, L.-Y. Tang, X.-W. Yang, Y.-Q. Li, H. Huang, X.-F. Zhou, B. Yang and Y. Liu, Chem. Pharm. Bull., 2010, 58, 1391-1394.

20 S.-K. Wang, S.-Y. Puu and C.-Y. Duh, Mar. Drugs, 2012, 10, 1288-1296.

21 L.-F. Liang, X.-J. Wang, H.-Y. Zhang, H.-L. Liu, J. Li, L.-F. Lan, W. Zhang and Y.-W. Guo, Bioorg. Med. Chem. Lett., 2013, 23, 1334-1337.

22 H. T. D'Armas, B. S. Mootoo and W. F. Reynolds, J. Nat. Prod., 2000, 63, 1669-1671.

23 H. Jayasuriya, K. B. Herath, J. G. Ondeyka, Z. Guan, R. P. Borris, S. Tiwari, W. de Jong, F. Chavez, J. Moss, D. W. Stevenson, H. T. Beck, M. Slattery, N. Zamora, M. Schulman, A. Ali, N. Sharma, K. MacNaul, N. Hayes, J. G. Menke and S. B. Singh, J. Nat. Prod., 2005, 68, 12471252.

24 F. J. Schmitz, D. C. Campbell and I. Kubo, Steroids, 1976, 28, 211-221.

25 M. J. Corral, M. E. González-Sánchez, M. Cuquerella and J. M. Alunda, J. Microbiol. Methods, 2013, 94, 111-116.

26 J. A. Plumb, Methods Mol. Med., 2004, 88, 165-169. 